\title{
Linking reproductive health to social power: Community health workers in Belize and Pakistan
}

\author{
Susana Galdos \\ Lucella Campbell \\ Patricia Mohammed \\ Debbie Rogow \\ Saumya RamaRao \\ Population Council
}

See next page for additional authors

Follow this and additional works at: https://knowledgecommons.popcouncil.org/departments_sbsr-pgy

Part of the Civic and Community Engagement Commons, Family, Life Course, and Society Commons, Gender and Sexuality Commons, International Public Health Commons, and the Women's Health Commons

How does access to this work benefit you? Let us know!

\section{Recommended Citation}

Galdos, Susana, Lucella Campbell, Patricia Mohammed, Debbie Rogow, Saumya RamaRao, Ali M. Mir, and Nicole Haberland. 2004. "Linking reproductive health to social power: Community health workers in Belize and Pakistan," Quality/Calidad/Qualité no. 15. New York: Population Council. 


\section{Authors}

Susana Galdos, Lucella Campbell, Patricia Mohammed, Debbie Rogow, Saumya RamaRao, Ali M. Mir, and Nicole Haberland

This case study is available at Knowledge Commons: https://knowledgecommons.popcouncil.org/departments_sbsr- 
Linking Reproductive Health to Social Power: Community Health Workers in Belize and Pakistan

\author{
er: \\ n
}
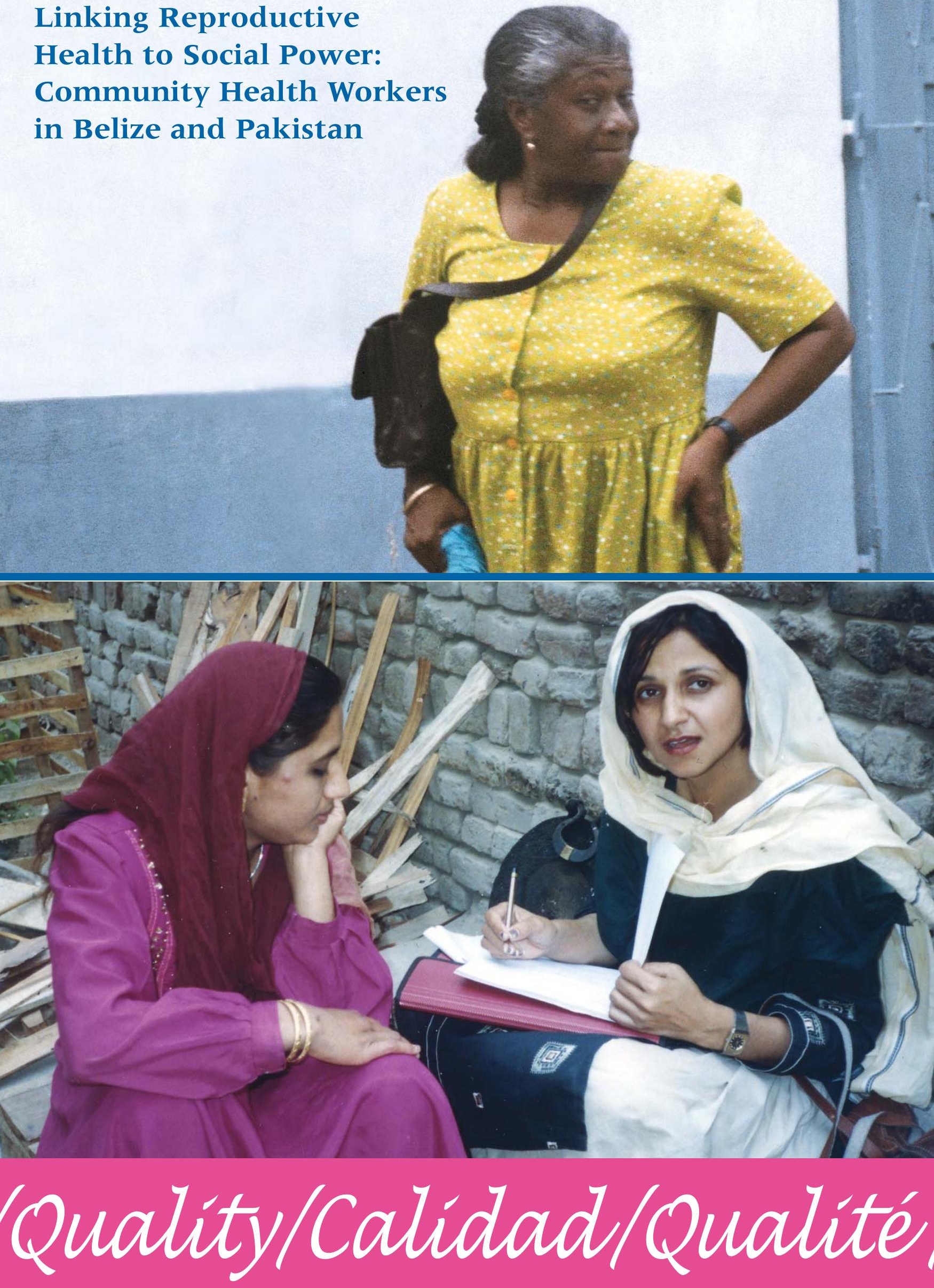


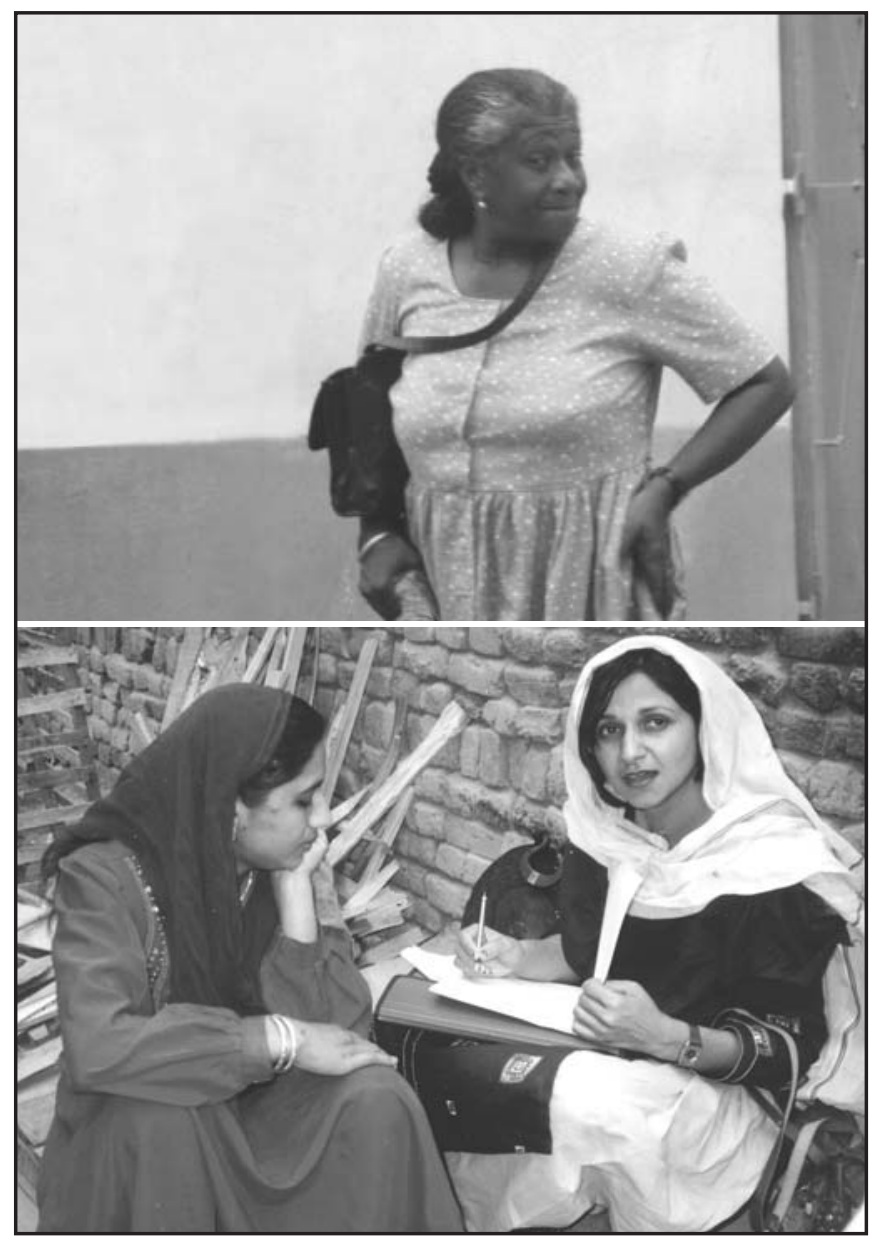

Linking Reproductive Health to Social Power: Community Health Workers in Belize and Pakistan 
Quality/Calidad/Qualité, a publication of the Population Council, highlights examples of clinical and educational programs that bring a strong commitment, as well as innovative and thoughtful approaches, to the issue of high-quality care in sexual and reproductive health. The series is based on the philosophy that people have a fundamental right to respectful treatment, information, choice, and follow-up from reproductive healthcare providers.

$Q / C / Q$ documents projects that are making important strides in one or more of the following ways: broadening the choice of methods and technologies available; providing the information clients need to make informed choices; enabling clients to become more effective guardians of their sexual and reproductive health; making innovative efforts to increase the management capacity and broaden the skills of service providers at all levels; combining health care, family planning, and related services in innova- tive ways; and reaching underserved and disadvantaged groups.

Projects are selected for documentation by an advisory group made up of individuals who have a broad range of experience with promoting quality of care in sexual and reproductive health. None of the projects documented is being offered as a model for replication. Rather, each is presented as an unusually creative example of values, objectives, and implementation. These are learning experiences that demonstrate the self-critical attitude required to anticipate clients' needs and find affordable means to meet them. This reflective posture is exemplified by a willingness to respond to changes in clients' needs as well as to the broader social and economic transformations affecting societies. Documenting the critical choices these programs have made should help to reinforce, in practical terms, the belief that an individual's satisfaction with sexual and reproductive health services is strongly related to the achievement of broader health and population goals.

Publication of this edition of Quality/Calidad/Qualité is made possible by support provided by the Ford Foundation, and by the Gender, Family, and Development Program of the Population Council. Statements made and views expressed in this publication are solely the responsibility of the authors and not of any organization providing support for $Q / C / Q$.

\section{Population Council}

The Population Council is an international, nonprofit, nongovernmental organization that seeks to improve the well-being and reproductive health of current and future generations around the world and to help achieve a humane, equitable, and sustainable balance between people and resources. The Council conducts biomedical, social science, and public health research and helps build research capacities in developing countries. Established in 1952, the Council is governed by an international board of trustees. Its New York headquarters supports a global network of regional and country offices.

Population Council, One Dag Hammarskjold Plaza, New York, NY 10017 USA

tel: (212) 339-0500 fax: (212) 755-6052 e-mail: qcq@popcouncil.org http://www.popcouncil.org

Cover photograph by Patricia Mohammed (top); Population Council/Pakistan office (bottom).

Issue No. 15 ISSN: 1097-8194

Copyright (C) 2004 The Population Council, Inc.

Any part of this publication may be copied or adapted to meet local needs without permission from the Population Council, provided that the parts copied are distributed free or at cost (not for profit) and that the source is identified. The Population Council would appreciate receiving a copy of any materials in which the text is used. 


\section{by Susana Galdos}

The early family planning pioneers needed audacity to utter the words "planned parenthood." Fifty years later, field lessons-many of them acquired painfully in the fight against HIV/AIDShave forced reproductive health educators to confront new " $\mathrm{P}$ " words: power and patriarchy. Stated in simple terms, a major factor in unwanted pregnancy and disease is women's/girls' lack of power to decide whether, with whom, and under what circumstances they will have sex. Research has consistently documented that this power differential often constrains females' ability to access information and health services, to initiate conversation with partners about intimate topics, to negotiate condom use, and to disentangle sexual decisionmaking from the threat of violence (Blanc 2001).

Many programs are now seeking to foster the social changes that will allow women to make and implement sexual and reproductive health choices. Clinical services and counseling can expand women's control over their reproductive health and their sense of agency; extended support is needed to improve the quality and expand the reach of such services. The static clinic, however, is not the primary venue for nurturing broader social changes. Rather, programs that reach people in their homes and communities can address the underlying norms and couple/family dynamics that determine whether a woman can get herself to a clinic in the first place, as well as defining what types of services will be offered when she arrives.

Community-based workers have long been a critical part of many health programs. For decades, many population programs engaged village promoterslargely as suppliers of contraceptives and of messages promoting small family size. With the emergence of AIDS, prevention programs began using community work- ers to distribute not only condoms but also information about safe sex. Often, the workers themselves have realizedlong before their program managers have-that they are carving out social space for new norms about sexuality, gender, and family. Sixteen years ago, Simmons et al. (1988) documented this phenomenon in Bangladesh: "In a social system characterized by strict patriarchal controls and extensive female seclusion, the presence of a female family planning worker acts as a link to modern ideas about reproductive choice." Indeed, those workers were quietly defying those patriarchal controls per se.

More recently, health programs have consciously built upon the role of community workers as exemplars and agents of broad social change. One of the most ambitious examples is ReproSalud, a tenyear, \$37-million women's empowerment project being implemented across Peru by Movimiento Manuela Ramos, in cooperation with USAID. ' Working largely through mothers' clubs, ReproSalud has trained women and men from the Andes to the lowlands to think about how gender fundamentally affects their lives; many of these individuals have undergone a lasting shift in values. Through subgrants to their clubs, they have gone on to educate their neighbors about sexual and reproductive health and women's rights, to foster social support, to advocate with local health officials for improved services, and to manage income-generation activities. With the project now in its ninth year, evaluation studies have documented that these empowerment approaches are resulting in fairly consistent increases in the use of family planning services.

In other countries, community-based HIV educators similarly are learning how

\footnotetext{
${ }^{1}$ For a description of the ReproSalud project, see Rogow (2000).
} 
to discuss such issues as economic power and physical violence within sexual relationships, as well as double standards for sexual behavior of males as compared with females. Haberland and Measham (2002) present reports on a number of health programs that are learning how to engage communities. Those engaged in efforts that place at least as much emphasis on women's rights as on their reproductive systems view this strategy both as the surest way to achieve desired health outcomes and as a matter of human rights.

This issue of $Q / C / Q$ focuses on two traditional family planning programs that undertook projects to help women enlarge their zone of influence in both the private and public spheres. In many ways, the two highlighted programsand the initiatives they have carried out-could not be more different. The first case study focuses on the Belize Family Life Association (BFLA), a nongovernmental organization in a small Caribbean country. BFLA, despite having virtually no experience in community work, organized public discussion groups on such topics as domestic violence, sexually transmitted infections, and teen pregnancy. The dialogues have sparked a change in many couples' communication about their relationship, increased family planning visits at the clinic, and transformed BFLA's profile both in local communities and at the national level.

The second case study recounts the experience of the Pakistani government, which has an enormous, but entrenched, target-oriented family planning program. Pakistan took a long-standing villageworker system and provided interpersonal communications training that highlighted how social power functions in the home, community, workplace, public agency, and society. The effort is now scaling up, improving the quality of interactions that thousands of workers have with tens of thousands of clients, and, with it, affording many women a slightly greater measure of autonomy and self-worth.

Despite their vast differences, the two case studies share some critical aspects. Both programs began by recognizing that women's lack of social power is a major obstacle to their being able to protect their own health. Both trained village workers to regard themselves in a different light, and to help other women enlarge their zone of influence both at home and within the provider system. Both included senior managers and policymakers in the training process, together with village workers. Finally, both stories remind us that we must begin by listening, for in both cases, it was the affirming voices of individual women and men from the community that grounded and reinforced workers' belief in the systemic reorientation of which they were part.

Translating even our thoughtful insights into reality depends on our being mindful of another $\mathrm{P}$ word: practicality. These case studies address such questions as: How can community-involvement projects establish goals that seek both to empower women and to increase their use of health services? What training approaches best prepare village workers to tackle issues of gender and power? What kinds of markers best indicate intermediate changes in norms and behavior related to sexual and reproductive health? The experiences in Belize and Pakistan provide concrete lessons for programs hoping to reinvent their own work on gender and in the community.

\section{References}

Blanc, Ann L. 2001. "The effect of power in sexual relationships on sexual and reproductive health: An examination of the evidence." Studies in Family Planning 32(3): 189-213.

Haberland, Nicole and Diana Measham. 2002. Responding to Cairo: Case Studies of Changing Practice in Reproductive Health and Family Planning. New York: The Population Council.

Rogow, Deborah. 2000. Alone You Are Nobody, Together We Float: The Manuela Ramos Movement Q/C/Q No. 10. New York: The Population Council. 


\title{
Beyond the Clinic Walls: \\ Organizing Public Dialogues on Sexuality and Gender
}

\author{
by Lucella Campbell, Patricia Mohammed, and Debbie Rogow
}

Geographically, the country of Belize sits nestled in Central America, between Spanish-speaking Mexico and Guatemala. Demographically, however, it is a Caribbean country, its history and people the products of the slave trade, colonialism, the indigenous Mayan culture, and migration. The population of approximately 250,000 is largely Englishspeaking and reflects a mixture of African, Mayan, and European roots. The economy revolves around agriculture, tourism, and fishing.

A third of the population of Belize is categorized as poor or very poor. Twentytwo percent of households are headed by women, and 36 percent of children leave school by the age of 14 (PAHO 1998; United Nations 2000). Girls who become pregnant are often barred from returning to school (United Nations 1999).

Belize shares many of the sexual and reproductive health problems facing most Caribbean countries (with the exception of Cuba). Unsafe abortion and other complications of pregnancy are leading causes of reproductive morbidity. Testing and treatment of reproductive tract and of sexually transmitted infections (STIs) are inhibited by stigma, perceived lack of confidentiality, and delays in obtaining laboratory results; as a result, many people resort to self-diagnosis and selfmedication. In addition, weak systems both for promoting and for analyzing Pap smears have resulted in high mortality rates from cervical cancer: 17 deaths per 100,000 women, well above both the developing country rate of nearly ten deaths and the global rate of eight deaths (Ferlay et al. 2001). One in 50 adults is infected with HIV (UNICEF 2001).

\section{An NGO Ripe for}

\section{Transition}

The Belize Family Life Association (BFLA) was established in 1985 as an affiliate of the International Planned Parenthood Federation. Its central mission was to provide contraceptive services, which were not available at that time. As other programs began responding to a broader range of sexual and reproductive health problems, however, BFLA failed to change with the times. Although its clinics began offering pregnancy tests and Pap smears, the clear emphasis remained on family planning and on achieving targets measured by "couple years of protection." Client-provider relationships were formal and hierarchical. Efforts to incorporate gender perspectives into the program were minimal.

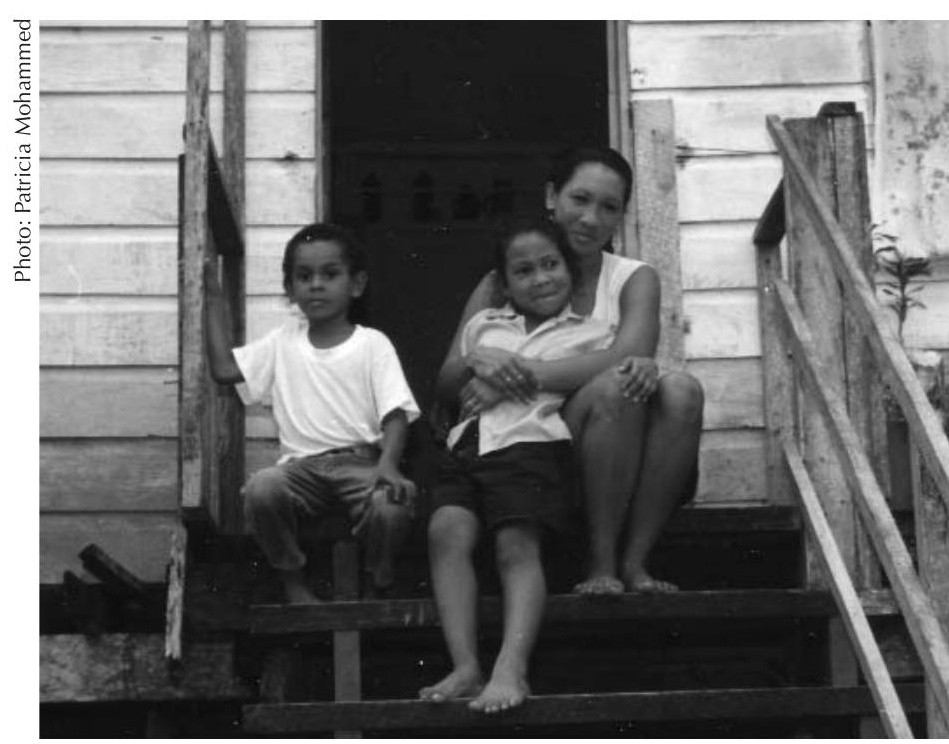

Women head 22 percent of households in Belize. Among the reproductive health problems they face are unsafe abortion and high rates of HIV and cervical cancer. 
BFLA's community component was particularly weak. The few staff members who engaged with the community sought to educate people about family planning and thereby recruit clients. Moreover, BFLA's political image was weak, in part because the hierarchy of the influential Catholic Church argued that BFLA was attempting to reduce the black population.

By the mid 1990s, with a stagnant client load and weak public image, BFLA recognized that its efforts to help Belizeans improve or care for their sexual health were seriously inadequate. The organization was facing its institutional limits and was not certain how to move forward.

Under the leadership of its Sexual and Reproductive Health Director, Judith Helzner, the International Planned Parenthood Federation's (IPPF) Western

\section{The organization faced one challenge} after another-cultural, political, institutional, and financial-in a process that was neither smooth nor simple. The staff conquered most of the obstacles with courage, creativity, and, perhaps most important, sheer grit.

Hemisphere Regional office developed a five-year project (1995-2000) in partnership with the European Union, aimed at helping three of its Caribbean-culture affiliates "transform [their] approach to community education." Together with Guyana and St. Lucia, the Belize affiliate was selected to participate. The central activity was for volunteer community health workers (CHWs) to establish public dialogues on sexual and reproductive health in villages across the country. These dialogues would serve the community by bringing people together to talk about their concerns in frank exchanges between men and women about such sensitive topics as sexuality, violence, and HIV. BFLA also hoped the dialogues would generate ideas for strengthening its services and increasing its client load, improve its image in the community, and enhance its ability to work effectively with the government to bring about positive policy change.

\section{Implementing the Community Involvement Project}

The project's objectives were written in modest language, but the task of realizing them was Herculean. Any organization trying to overcome a poor image in its community and to establish successful grass-roots work faces serious obstacles. Moreover, BFLA faced this challenge while attempting to implement a project that was thematically controversial and potentially explosive. Such community-based dialogues are increasingly being organized around the world in response to research documenting the central role of gender dynamics in determining sexual and reproductive health; Belizeans, however, had no tradition of this kind of communication, and BFLA had no experience in fostering it.

Not surprisingly, the organization faced one challenge after another-cultural, political, institutional, and financial-in a process that was neither smooth nor simple. What is, perhaps, surprising is that the staff conquered most of the obstacles with courage, creativity, and, perhaps most important, sheer grit. Furthermore, the journey led to a number of unexpected outcomes. The following pages describe the process by which BFLA met these challenges and reinvented itself as a more successful clinic, a valuable agency in the battle against HIV, a dynamic catalyst of social change, and a national actor in the health sector of Belize. 


\section{BFLA's Institutional Culture Did Not Fit the New Plan}

To implement the new project, BFLA needed to undergo a transition from a stagnating clinical organization to a dynamic community-based one dealing with sensitive issues. The BFLA Director at the time, Jewel Rosberg, recognized that a change in the very culture of the organization was needed before the board and staff could carry out the project successfully. With the support of IPPF's Western Hemisphere Region staff, she dedicated an entire year to foster that change and allow it to take root. This process took place with the Board of Directors, at the clinics, in the community, and in the training of staff.

Support for the project at the top level of the organization was critical. Together with Lucella Campbell (the IPPF Program Officer with regional responsibility for the Caribbean), Rosberg met with the BFLA Board several times. At the same time, Rosberg assembled a staff team to manage the community project. ${ }^{1}$

BFLA made a significant investment in preparing the staff at all levels. The first session was held for BFLA executive staff, clinic nurses, and several longstanding community health workers. ${ }^{2}$ Workshop participants learned how to promote two-way dialogues about sexuality and gender. Several activities were offered to help participants foster greater comfort with the topic of sexuality. These included exercises to help them distinguish between sex, sexual pleasure, and sexual relationships; opportunities to talk about their own experiences and attitudes; and conver- sations about local names for sexual and reproductive organs and about commonly held beliefs regarding sexually transmitted infections. A number of the participants went on to train a cadre of CHWs to carry out the project at the village level.

Although the main thrust of the project was to transform BFLA's community activities, the implications for the

\section{BFLA's Executive Director dedicated an entire year to fostering changes in the organization's culture.}

clinics were immense. For example, if community discussions emphasized prevention and treatment of sexually transmitted infections, the BFLA clinic was going to have to do a better job of providing that service. To that end, investments were made to expand laboratory facilities at the five BFLA clinics throughout the country. Clinic nurses were also trained in basic counseling approaches.

An institution's culture does not change in a matter of months, but all of these efforts signaled to BFLA's staff and Board that the organization was embracing a new philosophy and working style. From the president of the Board to the receptionist, everyone was expected to develop new skills and approaches to help make the transformation a real one.

\footnotetext{
1 The management team consisted of Evaluation Director Mervin Lambey, Director of Information, Education, and Communication Sheila Middleton, Team Coordinator Rafael Sosa, and Rosberg.

${ }^{2}$ The workshop was led by Tony Klouda (an IPPF trainer), Lucella Campbell, and Diane Haylock (from the Society for the Promotion of Education and Research, a local NGO).
} 


\section{Isolation from the Community}

BFLA's next task was to craft a new relationship with the community. Its public image, however, was less than ideal for carrying out a grass-roots project. The organization had never sought community feedback in designing its services, and BFLA was not the first name that came to mind for most Belizeans when they were asked which organization had roots in the community, listened to their concerns, and worked together with them. Rosberg says that the prospect of starting to change BFLA's image was daunting at first.

Daunting perhaps, but it was not overwhelming for the determined BFLA staff. For the first time in its history, BFLA went to the community it served to learn. As a first step, project leaders met with established local leaders and canvassed villagers informally. What were the villagers' primary areas of concern? Could BFLA be accepted as a comprehensive sexual and reproductive health organization? Which would be the best approaches for reaching people? Who wielded influence? Whom should BFLA recruit to serve as volunteer CHWs? How could BFLA foster a productive discussion with religious leaders? Might BFLA count on the leaders' support in facilitating the community dialogues that were to be the heart of the program?

These discussions provided the project with valuable information and essential partners. Although some village leaders expressed skepticism that men would allow their wives to participate in open discussion groups about sensitive topics, most were encouraging and helped to guide BFLA as it reached out to respected members of the community. BFLA followed the leaders' advice in recruiting volunteer $\mathrm{CHWs}$; the organization was able to engage 30 female residents - housewives, teachers, nurses, and government health workers-from ten communities to join the project as the first cohort of volunteer facilitators.

These women participated in a fiveday $\mathrm{CHW}$ training, similar to the initial workshop provided to the BFLA staff. This workshop aimed to provide the participants with the skills-and the courage-to launch public, communitybased discussion groups on aspects of sexuality, gender, relationships, and reproductive health, as well on how BFLA could improve its services. Some of the initial exercises were aimed at helping the trainees expand their understanding and rethink their own attitudes about such topics as gender roles, sexual coercion, homosexuality, and masturbation. Subsequent activities prepared them to handle in a group setting a variety of concrete problems that people in the community might raise, from incest to alcoholic husbands to fears about HIV. For example, there were role-play exercises depicting a man who wanted to have sex when his wife did not; after the role-playing, the group made suggestions they could offer if such a problem emerged in a community discussion. The trainers also provided each future volunteer $\mathrm{CHW}$ with a manual that included a definition of her role, described steps to take in community outreach, offered sample discussion topics, listed reference materials on sexual and reproductive health topics, provided referral information, and gave tips on managing group dynamics. With their newfound knowledge and confidence, a manual, and a BFLA-issued bicycle, the pioneer $\mathrm{CHWs}$ were ready to venture into the villages across Belize, from Orange Walk to Guinea Grass, San Lázaro to Teakettle, and Chan Chen to Patchakan. 


\section{Hostility from the Church}

Institutions and daily life in Belize are deeply influenced by organized religion, particularly Roman Catholicism. Nearly two-thirds of the population define themselves as Catholic. Religious instruction and chapel attendance are part of the curriculum in public schools (USDOS 2003). Catholic and Pentecostal leaders opposed to contraception have criticized BFLA over the years, and several warned villagers not to cooperate with BFLA's new community project.

BFLA recognized that any effort to penetrate the community would require an improved relationship with at least some representatives of the Church. Lorna Perez, Center Coordinator in Orange Walk District, recalls, "At the beginning, it was difficult. The northern districts are mostly Catholic, so we turned to [Protestant] evangelical leaders. They are not the majority, but they have a hold, and some of their members use our services or were our contact persons. These church members had to coerce their leaders a bit to listen to people, but this is how they built a base."

By and large, the pastors were receptive to the idea of BFLA's expanding its services beyond family planning to include, for example, prevention and diagnosis of cervical cancer and counseling for infertility and nutrition. They joined with the community leaders in supporting the idea of a forum to improve communication between men and women, aimed at reducing the power imbalance that leads to coerced sex, unwanted pregnancies, and STIs. The pastors also became more sympathetic than they had been about family planning. As one pastor said, "I really don't know your case. I really don't know your situation at home. If you think you need to do this, the Lord will understand." The support of religious officials was invaluable to the new project. Pastors or church members announced BFLA events to their parishioners, and in some villages BFLA was able to use the church facilities for group discussions or other educational activities.

Nonetheless, some church leaders actively opposed the project. Rosberg explains, "The church leaders held a retreat for village leaders and tried to discourage them from having anything to do with BFLA. Since the villages are small, that slowed us down for a time. BFLA's staff offered reassurance to the communities, and reminded women that they had the right to choose what was relevant for their lives. Eventually, we were able to counter that pressure."

The support of the pastors and other influential religious leaders was important not only for establishing the com-

\section{A staff member explains, "Some church members had to coerce their leaders a bit to listen, but this is how they built a base."}

munity-based discussion groups but also for easing the stigma associated with the BFLA clinics. Better relations between BFLA and the church presumably played a role in the increase in clients' visits to BFLA clinics around the country. The support of the church also improved BFLA's image among some previously hostile government officials and policymakers, opening the door for the organization to play a different role in the national reproductive health policy arena. 


\section{Too Many Problems Identified by the Community}

With the aid of community leaders, BFLA's newly trained volunteer CHWs organized discussions in ten villages and alerted the community about them with signs, church announcements, and radio bulletins. The key message in the announcements was to "Come join a discussion and improve our community life," but they also listed a particular topic. The CHWs went to the discussions prepared to listen rather than to lecture. Of course, they anticipated that community members would air certain reproductive health concerns and needs, particularly those related to cervical cancer, HIV/AIDS, and STIs.

In most places, attendance was good, although relatively few men came, and the discussions got off to a smooth start.
Some participants offered suggestions for improving the quality of services, for example, by offering effective confidentiality protection for STI results. The facilitators noted these requests, and BFLA soon followed up with a protocol assuring that only physicians would have access to STI results.

The facilitators were not prepared, however, for the wide range of topics that were broached by participants. Some of the needs the villagers expressed-for example, for better employment and housing-were simply outside the scope of BFLA's efforts. Moreover, when speaking about their health concerns, participants mentioned diabetes and high blood pressure more than their sexual and reproductive health problems.

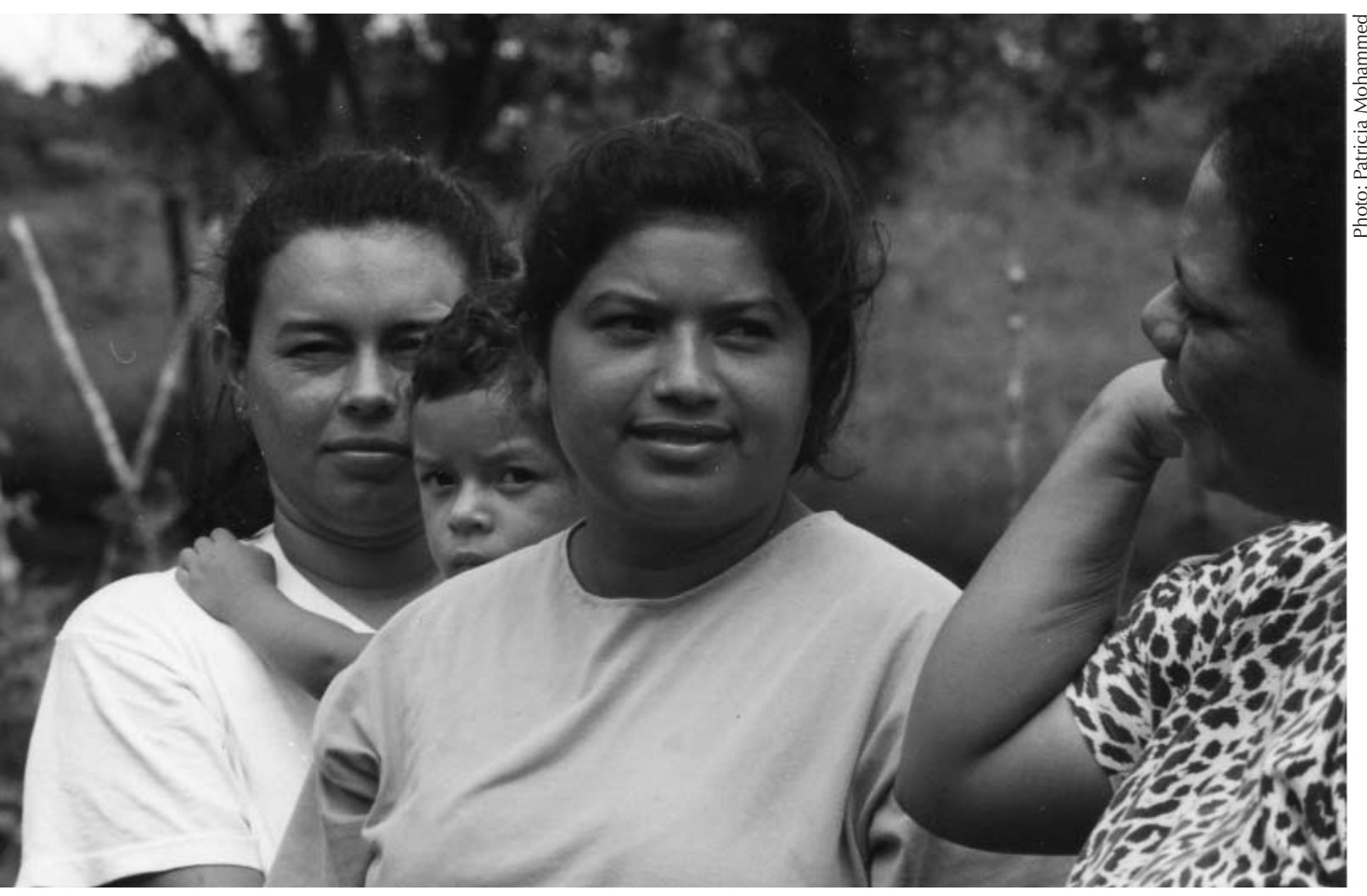

The CHWs were not initially prepared to deal with many of the women's concerns. At first, these concerns included worries about unemployment and diabetes; later on, the women asked about homosexuality and masturbation. 
The CHWs gradually gained experience in explaining that BFLA could help villagers deal with sexual and reproductive health issues. Many of the participants' concerns touched on matters of gender and sexuality. To foster dialogue, CHWs would pick up on casual comments participants made, asking them to explain in greater depth what they meant. They asked participants provocative questions about relationships between men and women. They also organized role-playing. Although some individuals were shy about speaking of their needs and required one-to-one contact with the $\mathrm{CHWs}$, the community as a whole nearly overwhelmed the $\mathrm{CHWs}$ with concerns. Once villagers grasped that the facilitators were dealing with "deep matter," they began opening up in a way most of them had never done, certainly never publicly. Hopes, fears, resentments, and dreams about love, sex, companionship, marriage, and death came to the surface. As one CHW said, "It's as if we opened a dam and the water burst." The dialogues had come to life.

Some participants raised concerns about such sensitive topics as masturbation and homosexuality, topics that the facilitators' training had not sufficiently prepared them to handle. As Lorna Perez explains, "At first, people were not even comfortable with their own sexuality, so they could not deal with these issues. So we opened discussions with various staff, including the psychiatric nurse-practitioner, the social worker, and the gynecologist. There has been a big transition: Now the workers can deal with these issues more comfortably, or at least listen and encourage the client."

The CHWs also had to respond to a wide range of concerns by covering different topics in the discussions. Over the course of time, the discussions typically have included parenting, domestic violence, teenage pregnancy, abortion, suicide, family planning, gender issues, AIDS and other STIs, and drugs. By listening to the villagers, the $\mathrm{CHWs}$ also

Once villagers grasped that the facilitators were dealing with "deep matter," they began opening up. As one CHW said, "It's as if we opened a dam and the water burst." The dialogues had come to life.

learned which issues were of particular concern in their communities and structured sessions on those topics. For example, in Scotland Halfmoon village, Iva Charlesworth found that schoolgirls were experiencing constant peer pressure to be sexually active, and she developed workshops for young people on sexual and reproductive health. When several women in Crooked Tree village lost their babies, CHW Ava Tillett began providing education about infant care. Many girls in Bullet Tree village marry young; Gloria Garcia, the CHW there, married at 14 herself, so she focused on contraceptive education. 


\section{The Need to Reach Men}

Some women explained that they could not attend the discussions because they knew they were not likely to get their husbands' "clearance" to do so. Lorna Perez recounts:

One lady told us her husband did not want her to come to the sessions. We made a home visit, and he said, "All you people do is put things in these women's minds so that they become rude to their husbands." We tried to get him to tell us what he thinks we needed to discuss — with men or with women-but he just said, "Men don't go to meetings; men have work to do." He also didn't want his wife to use contraceptives because he felt she would start having sex with other men at home when he went to work. But she was already taking oral contraceptives behind his back; she was tucking them in a vitamin bottle to use without his knowing.

Even more challenging was convincing men to participate in the discussions. As one $\mathrm{CHW}$ recalled, "We had meetings; sometimes it was a large amount of ladies, sometimes 60-one was about 100 and more-mainly women and [only] about eight or ten men." The women attending the discussion expressed their frustration that their husbands were not joining in.

High on the women's list of concerns was their husbands' patronage of brothels. In small, isolated villages such as Guinea Grass, where transportation is limited and few men have cars, bar owners regularly imported sex workers on weekends. Lorna Perez explains, "The women knew that if you can't find your husband, someone will tell you, 'Oh, he's at [the bar].'"

Women whose husbands frequented the bars-often staying for the entire weekend-were upset by the health and economic consequences of the sexual commerce. As Sandra Flores, the BFLA Orange Walk Community Coordinator described the women in one village, "Pegaron el grito al cielo" ([the women] ... screamed out to the heavens") The wives also knew that commercial sex at

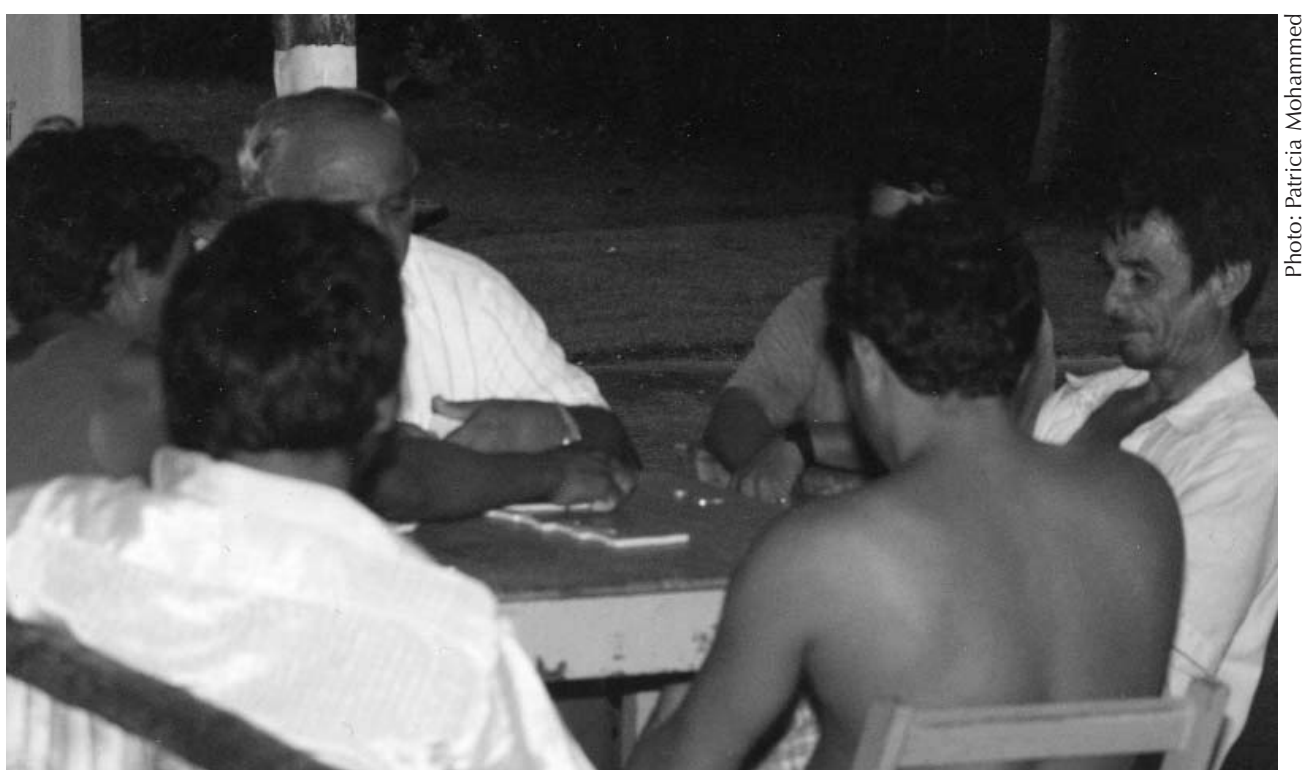

At the start, few men attended the discussions. In one village, a group of men playing dominoes nearby a discussion did not even look up from their game to participate. 
bars was permitted by the all-male village council. When neither the heavens nor the council offered a solution, they approached Rosa Cima, the BFLA community health worker who lives in Guinea Grass.

Rosa and her three local coworkers, who had been selected by the community and were well regarded, invited the men to attend community meetings; for the most part, however, men were hesitant to participate. Some CHWs went to the men's homes and found most husbands willing to talk privately. The CHWs were able to teach these men how to use condoms and to answer their questions about STIs and HIV.

In some districts, men began to participate in the discussions, which were attended mostly by women. Ironically, HIV/AIDS proved to be the topic that drew men to participate; in fact, of those in attendance at the HIV/AIDS discussions 85 percent were male. Whereas many women had been hesitant to acknowledge publicly that their husbands were having sexual relations outside the home, the men were less constrained about discussing this behavior.

In other settings, Perez explains that BFLA staff were able to reach men through clinical services:

We tried to talk to the men who were waiting for their transportation home from the fields, but it was hard. They were headed for the bar, and the commercial sex workers. There was peer pressure among them not to listen to female health educators. They told us, "That's where we get our fun, we're tired of going home and listening to the children crying."

Then, one man came into the clinic with pain, burning, and discharge, and said he had been at the brothel. His wife had sent him because she had talked to us. This man shared with the other men. The next time I went to talk to them, they had a lot of questions.

Perez says that it took many years to overcome men's resistance to the discussions. She adds, "There is more respect now. The attitude has changed." Nonetheless, for the most part, the discussions still tend to be either for men or for women. The avenues for reaching men are different from those for reaching women, and the CHWs tend to organize discussions for men at their workplaces. Moreover, the $\mathrm{CHWs}$ feel that they need to discuss certain issues with women separately from men. The issue of male promiscuity is one such issue. Perez explains that men argue that it is expected and that it is a natural thing for them to have extramarital affairs; they claim, "If you are not doing it, your wife is controlling you." On the other hand, the women tend to approach the topic feeling concerned but helpless, saying, "There's nothing I can do about it." She explains that the CHWs realize that their real topic was empowerment and how to help women gain the ability to negotiate condom use.

Occasionally, the $\mathrm{CHWs}$ have had to face threats to their own safety from the irate husbands of other women. Some have had to rely on their own husbands to protect them from such aggression. Perez recalled one man who had been arrested after his wife reported him for physical abuse. He pursued the CHW, blaming her for the problem and threatening to beat his wife again. The CHW's husband stepped forward and told him, "You are looking for problems. If you do it again, you will be in serious trouble." Finding support in the male community has been important for CHWs challenging prevailing norms tolerant of violence. 


\section{Discussions of Power and Gender Became Too Sensitive}

Some of the problems that emerged in the discussions simply seemed too daunting to imagine "fixing." The most common problems involved issues of gender and power, husbands' patronage of sex workers, control of household funds, domestic violence, and incest. In the box below, Lorna Perez recounts how three men turned a discussion intended to focus on menopause into a heated discussion about control over money, family life, and male social support.

In some districts, CHWs realized that they would have to do more than facilitate group discussions. In a number of villages in Orange Walk, BFLA made an effort to work directly with the bar owners and the sex workers. With guidance from project leaders, coordinators in three districts established relationships with the community bars. Supplied with condoms, the BFLA facilitators approached the owners of bars directly and persuaded them to distribute the condoms at the site where sex workers met their clients. The bar owners consented to sign a cooperative agreement, under which they would purchase condoms from the project and the public health department would provide screening and treatment for infections. The bar owners also

\section{Confronting Gender Power in Guinea Grass}

\section{By Lorna Perez, Center Coordinator}

Just after Village Council elections in Guinea Grass, three newly elected leaders stepped into our discussion, explaining that they were there only in an "official capacity since this is a woman's meeting." When we sought their input on how to get men to participate in the discussions, they answered, "We don't have time to be wasting." "We are tired after work. We need to relax, not listen to a lot of talk." "It's better to relax with a cold beer and a woman who won't hassle you."

The women were so upset that they started sharing their frustrations about home life. They spoke up about the violence they experienced when their husbands came home drunk, about financial constraints when their children were sick or needed something for school, and about times when there was nothing to eat, yet they had to find something to feed the children and their husbands. Throughout this time, the men were quiet.

After a while, everyone realized that one woman was crying silently. I did not realize that she was the wife of one of the men present. The church pastor's wife got up and asked her if she had anything to say.

She turned directly to her husband and said, "I thought I was the only one going through this. I realize that most of these women here have husbands who behave like you do. You never know how I make it through the day. You never give me money to buy. At the end of the week you pay part of the food bill and spend the rest drinking with your friends, and when I go to the store they refuse to give me any more credit. You sleep through the nights when the baby is sick. I don't get to sleep, and yet I have to get up early to prepare your lunch, then I have to do the laundry, see the children off to school, and sometimes get a ride to take the baby to the hospital. At the end of the day you come home and expect your food to be ready and don't bother to ask me how my day went." 
cooperated in helping the BFLA staff reach the sex workers, who received training on HIV/STD prevention and condom use. According to Perez, these efforts had a significant impact on STI prevalence rates. ${ }^{3}$

In this community, the group did not address the economic aspect of the women's complaint, but it did begin to create conditions for challenging men's sexual practices. As men in the commu- nity became more comfortable discussing their sexual health, a number of them began joining their wives at the public meetings, and their presence allowed for the beginning of an improvement in communication between men and women. For the first time, women were able to voice their concerns about their husbands' liaisons with sex workers directly to their husbands in a supportive setting.

\footnotetext{
${ }^{3}$ Although the bar owners continue to distribute condoms to the sex workers (who tend to be illegal immigrants with a quick turnover), the STI rate has climbed back up. Perez cites two factors. First, the Ministry of Health, strapped for resources, has stopped providing screening and treatment. Second, the trade-free zone in Belize has created dramatic increases in work-related physical mobility, often separating husbands and wives and resulting in an increase in extramarital relations.
}

This woman was speaking with so much pain that none of the men could have ignored it. One of them turned to her husband and said, "I didn't know you treated your family so badly." He answered, "You know, you do the same-we drink together."

I interceded and asked the men if they were aware of what these women were describing. They answered that their wives had never told them. An argument was about to start up again, but we tried to divert the discussion to a more positive tone, asking them why they thought men patronize the local bars. What did men do before the bar opened? How did they relax? Was there more money for the family when the bar wasn't there? Did they spend more time with their families before?

The most beneficial exercise was getting them to put on paper the way in which men spend their money. We encouraged them to write on the easel. The women helped them remember, which-since it was a fun activity-eased the tension.

When the men were finished we asked them to comment. What caught their attention was the small percentage they were giving their families out of their salaries. The women, in a much quieter tone, were saying, "Do you understand what we are talking about?" This started a discussion among the three men. They identified ways to cut down on personal expenses, including paying fewer visits to the bar, and some ways to spend more time with their children.

These village leaders agreed to invite other men to a meeting to discuss STIs and HIV/AIDS. That meeting ended in a very positive mood. The men stayed behind joking about how much money they would have if they hadn't spent it the way they did. Women left feeling confident they had accomplished something by getting three men to listen.

We kept the momentum going and were invited to their village meeting, where we were introduced as "the people who would be providing education on different family life topics."

This same village council denied a permit for the local bar to continue functioning. It was closed, and I must say, a lot of the women were happy. 


\section{Transportation Problems}

Transportation in rural Belize is minimal and expensive, and many women lack access to discussion-group sites. In particularly remote areas, CHWs began to travel to women's homes to foster dia-

\section{Transportation in rural Belize is}

\section{minimal and expensive. The}

absence of public bus routes

presented a problem for $\mathrm{CHWs}$

and villagers alike. day (funds are insufficient to provide lunch). These sessions provide opportunities for training updates on technical issues and for the workers to exchange stories with each other about the challenges they faced. To ensure adequate monitoring, the project also developed a set of forms so that CHWs could enter information about the number and content of their group discussions, home visits, and clinic referrals. CHWs submit their forms on a monthly basis, and BFLA compiles the information.

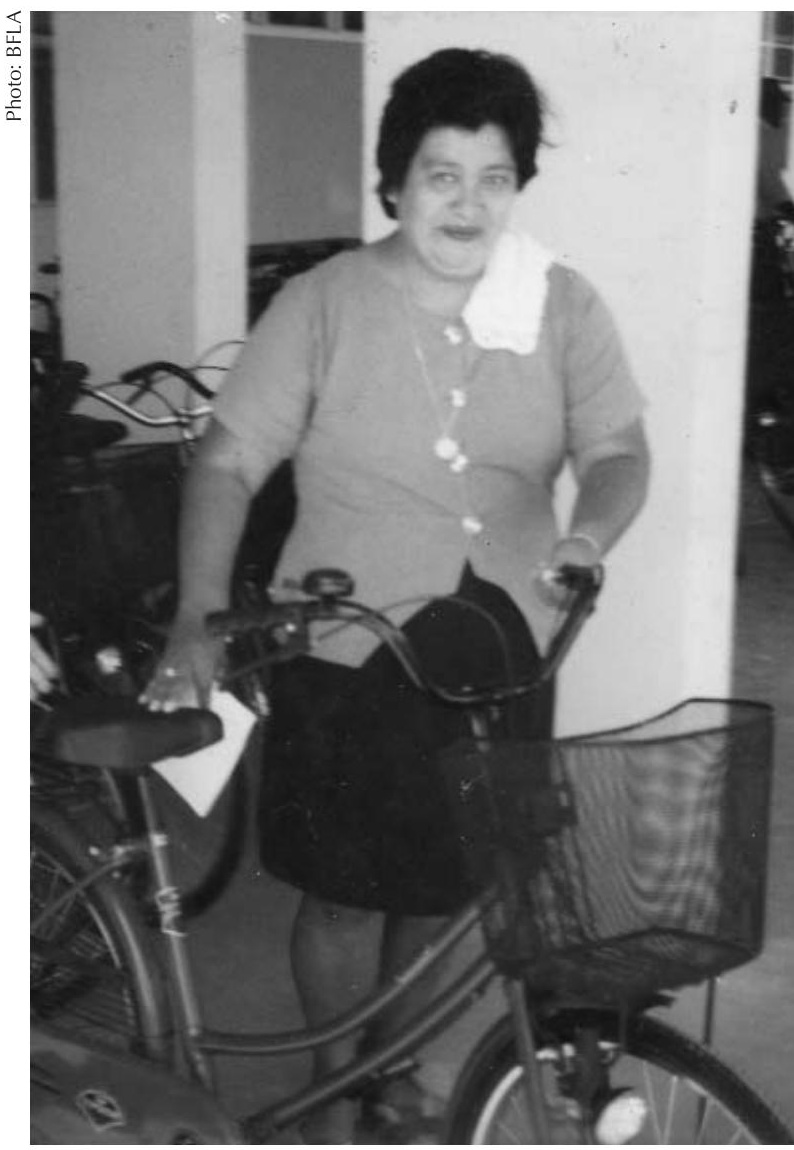

CHWs of all ages were issued bicycles to enable them to traverse from village to village across bumpy roads, so that they could reach outlying homes.

logue and to provide information and some contraceptives. Such travel is a challenge for the CHWs as well, who, in the absence of public bus routes, must walk or ride bicycles for long distances in order to travel between villages and reach outlying homes. To manage their travel burden, they frequently alternate which clients they visit each month.

Transportation is also a barrier to visiting BFLA clinics. In response to complaints that clinic sites were inaccessible, BFLA established special one-day miniclinics in the villages. In one community, the CHW campaigned for all of the women in her community to receive Pap-smear analyses, and to that end worked with BFLA to establish a local two-room clinic. In the second phase of the project, the FPA also gave select community facilitators the responsibility of distributing condoms and oral contraceptives.

Finally, the lack of good roads makes it difficult to bring the CHWs together for ongoing exchange, monitoring, and training. The project is able to provide transportation costs for the CHWs from each district to meet monthly for a half- 


\section{Young People Were Not Participating}

BFLA staff knew that they would have to find another avenue by which to reach adolescents. They began by targeting out-of-school teenagers, both because their needs are particularly great and because many of the schools were controlled by conservative religious leaders who were unlikely to welcome BFLA. To this end, BFLA opened a teen center, recruiting and training teenagers to facilitate both individual and group sessions with their peers. Based on feedback from these recruits, the teen center expanded the program to include dance and drama, sports, and skills development. Despite encountering some problems (for example, inadequate space and a failed effort at income-generation), the teen center has thrived.

BFLA was soon emboldened to add a school-based initiative. The staff moved forward although they were not prepared to offer classroom presentations on sexual health. With typical doggedness, they trained themselves with the aid of local materials and began reaching out to public schools, offering to provide reliable information to students about such topics as menstruation and sexuality.

A handful of teachers welcomed BFLA. In most cases, however, staff had to be aggressive in persuading principals and teachers to allow them to meet with the students. Some educators insisted on attending an initial presentation before granting approval. Lorna Perez recalls the determination it took to keep going: "At one school, I had been invited by a teacher, not by the administration. The principal met me by the gate. I was escorted out of the school, told not to put my foot there again. That's how bad it was then."
As in the discussions with adults, the CHWs found that some topics were more sensitive than they had anticipated. For example, a CHW in Cayo district broached the issue of "good and bad touching" with 11-year olds at a school presentation, and encouraged children to report abusive touching to someone they trust. A week later, a girl called the $\mathrm{CHW}$ at home to disclose that her teacher had tried to touch her "private parts." The worker had never before dealt with such a situation. Subsequently, the girl described her experience to the police, who investigated, with the result that the teacher was fired. Consequently, BFLA added a psychologist to the clinic staff for counseling women and girls who have been victims of incest or other forms of abuse.

Gradually, BFLA established its credibility, and more schools opened their doors to the organization, including many Protestant and even some Roman Catholic schools. Perez continues, "If we were to leave it up to the people who say no, we would not be going today. We have managed to build a rapport and establish relationships with key persons, for example, teachers and principals, and with the Ministry of Education staff. The demand now is huge."

The teen center is now among BFLA's core projects. In its most successful year, 3,513 teenagers used BFLA's teen center and/or clinic, and peer leaders counseled 2,551 adolescents in small groups and individually. Moreover, many children have begun to discuss the BFLA presentations with their parents, who then approach the CHWs with questions of their own. The efforts to educate young people have been lauded by village communities and by the media, ultimately improving BFLA's public image. 


\section{A Public Profile That No Longer Fit}

By 1996, a year in which the CHWs conducted no fewer than 574 group discussions, BFLA realized it had transformed its identity and mission. Listening to local people and building authentic relationships had resulted in communities' feeling ownership of the project. Indeed, when the project lost outside funding at one point, some communities assumed financial and programmatic responsibility for it. Yet BFLA retained its old sterile, clinical public image. Rather than let time erode the old image, the organization launched a media campaign simultaneously to promote its

BFLA went from providing 11 percent of the country's family planning services to providing 20 percent since initiating a project that focused primarily on noncontraceptive issues. Moreover, some communities have assumed financial responsibility for the project locally. BFLA credits listening to people and building authentic relationships.

new services and to reflect its personal approach. As part of its image enhancement the organization adopted a new slogan: "Belize Family Life Association A 21st-century Response to Your Family's Reproductive Health Needs."

\section{BFLA Today}

BFLA's community-involvement project faced challenge after challenge and worked through each one with determination and by listening to the community. Assessing the effectiveness of this project has not been easy. The European Union, which funded it, retained IPPF as consultants to provide additional monitoring and evaluation. ${ }^{4}$ Information systems were instituted to maintain detailed records on service-giving. Social relations between men and women, however, are determined by a number of factors, and the methodologies needed to assess social empowerment interventions are still in the early stages of development. Staff from IPPF and BFLA conducted a series of focus-group discussions and in-depth interviews with project volunteers, village leaders, and community members to learn about changed attitudes. The findings have not been systematically analyzed, however. Nonetheless, most staff would agree with the comment of one community health worker, who stated, "Plenty of the women say that these meetings are making them talk to their men about things they would never discuss before."

Facing these challenges and surviving is a success story for any organization. For BFLA, the journey itself has strengthened the organization and has had a number of positive, and fundamentally interrelated, outcomes extending beyond the specific obstacles that were overcome. Even after the five-year project funding was discontinued, community discussions continue in many areas. Several salient achievements are highlighted below:

\footnotetext{
${ }^{4}$ The experiences in St. Lucia and Guyana followed similar trajectories. In Guyana, for example, the Executive Director spent months working with the Board of Directors to ensure adequate institutional support for the project. The Guyana affiliate also expanded its services to include colposcopy, counseling, and improved STI care. As in Belize, the clinic's enhanced community image and expanded service offerings resulted in increases in service use and invitations to join government delegations.
} 


\section{Increase in Service Use}

The steps BFLA took to improve women's access to services, along with the impact of the discussion groups on women's decisionmaking, had a marked effect on BFLA's service statistics. By 2000, the clinic was providing a greater number of Pap-smear and pregnancy tests than it had performed previously, and had added STI diagnosis and treatment, sexual and reproductive health counseling, colposcopy, and breast examinations. The most significant increase in service use, however, was in contraceptive visits. In 1994, before the community-involvement project began, BFLA provided contraceptive services for 12,468 visits; this figure rose in 2000 to 17,801 . Indeed, BFLA went from providing 11 percent of the country's family planning services to providing 20 percent since initiating a community-involvement project that focused primarily on non-contraceptive issues.

In 1998, BFLA experienced an extended gap in funding for the community-involvement project. Although Jewel Rosberg was concerned that the entire project might fall apart, this difficult period proved how successful BFLA's efforts had been. The training that the volunteers received had equipped them to continue their work in the community without much supervision. In one community that had identified the need for more accessible services, the villagers themselves contributed funds to build a BFLA clinic. Rosberg believes this result is easily explained: BFLA had built relationships with schools, social service agencies, psychologists, Ministry of Health professionals, drug-prevention-council programs, and youth programs. All of these agencies were, for the first time, referring clients to BFLA.
Improved Care for

\section{People with HIV}

During the discussions, people shared their discomfort about the experience of living with people with AIDS. The facilitators asked how BFLA might respond to this concern. BFLA surveyed 16 people with AIDS about their needs and learned

The CHWs in one village became

the first women ever elected to their village council.

that they wanted counseling for themselves and others to deal with their fear and shame. In response to this input, BFLA added counseling services for people with AIDS and for their friends and family. BFLA also presented the findings of its interviews to the government, resulting in the formation of a task force for people with AIDS. BFLA remains a prominent member of that task force.

\section{Empowerment of \\ Community Health Workers}

The Community Health Workers realized they were tackling issues that everyone had thought were intractable. Gradually, they began to see themselves in a different light as well. As one worker commented in a project-evaluation interview, "The people I talk to say that these meetings help them a lot. They learn a lot. Must be true, because I know it really, really helps me."

Moreover, as has been noted among $\mathrm{CHWs}$ in other countries, these workers often become important leaders in their communities. The volunteers in Belize grew to assume a high level of respect and influence in their villages. In one village, CHWs from the project were elected to serve on a village council that had never before had a female member. 


\section{BFLA's Official Role In Health-sector Reform}

As BFLA expanded its services and fundamentally changed its relationship with the community, the organization also gained respect. It was invited to join a number of local consortia, and the government provided a physician to perform colposcopies at a BFLA clinic. At the national level, BFLA was invited to participate in a number of important committees, including the National AIDS Commission, the Women's Issue Network, the National Association for the Prevention of Child Abuse, and the National Committee for Families and Children.

Eventually, the government invited BFLA to join the National Health Sector
Reform Committee. When this body designed a plan for delivery of health services through a government insurance program, BFLA was selected as one of three agencies to provide reproductive health services. Jewel Rosberg acknowledges that it is unlikely that BFLA would have been awarded this role if it had remained essentially a family planning agency with a limited mandate. She commented, "The changes have conspicuously altered BFLA's ability to forge alliances and ensure inclusion in the policy and decisionmaking processes that affect the institution and its ability to operate effectively in this country."

\section{Lessons Learned}

This project redefined the identity and operating style of the association. Expanding into broader areas of sexual and reproductive health was fundamental to achieving greater legitimacy at the community level, as well as with the government. The institutional changes triggered by this shift of emphasis were greater than anticipated, however. Programs broadening their mandate need to consider the time and process required for developing support at the policy level, implementing service-delivery changes (including securing equipment) that may result from community input, and building expertise in handling sensitive issues.

Individual home visits were helpful initially for engaging shyer women, as well as for reaching men. The dynamic of a group discussion was essential, however, for highlighting the organization's new profile in the community, energizing the reflection process, and breaking individuals' sense of isolation with their problems.

Allowing the community workers to respond to perceived local needs laid the groundwork for BFLA's sustainability. These workers became the catalyst for change in the community and demonstrated creativity and stamina in facing challenges. For their part, community members were motivated to assume financial and programmatic responsibility for the project when funding was cut.

Investing in a broad sexual and reproductive health educational effort resulted in an increase in contraceptive visits at village clinics. 


\section{References}

Ferlay, J., F. Bray, P. Pisari, and D.M. Parkin. 2001. Globocan 2000: Cancer Incidence, Mortality, and Prevalence Worldwide. Lyon: International Agency for Research on Cancer Press.

Pan American Health Organization (PAHO). 1998. "Health situation analysis and trends: Summary country chapter (Belize)" from Health in the Americas, 1998. <http://www.paho.org/English/SHA/ prflBEL.htm.> Accessed 28 January 2004.

UNICEF. 2001. "Information by Country: Belize." <http://www.unicef.org/infobycountry/belize_statistics.html.> Accessed 29 January 2004.

United Nations. 1999. "Committee on rights of child concludes consideration of Belize Report on compliance with convention." Press release. <http://www. unhchr.ch/huricane/huricane.nsf/0/867C E0D30D363F95802566FA005D38B4? opendocument $>$. Accessed 27 January 2004.

2000. The World's Women 2000: Trends and Statistics. New York: United Nations Publications.
United States Department of State (USDOS). 2003. "Belize." In Annual Report on International Religious Freedom. Washington, DC: USDOS. <http://www.state.gov/ $\mathrm{g} / \mathrm{drl} / \mathrm{rls} / \mathrm{irf} / 2001 / 5564 . \mathrm{htm} .>$ Accessed 15 January 2004.

\section{Further Reading}

Campbell, Lucella and M. Lambey. "How a family planning association turned its approach to sexual health on its head: Collaborating with communities in Belize." Responding to Cairo: Case Studies of Changing Practice in Reproductive Health and Family Planning. Eds. Nicole Haberland and Diana Measham. New York: Population Council.

Helzner, Judith. 2002. "Transforming family planning services in the Latin American and Caribbean region." Studies in Family Planning 33(1): 49-60.

\section{A c knowledgment}

The authors gratefully acknowledge Lorna Perez of BFLA for her significant contributions to this article.

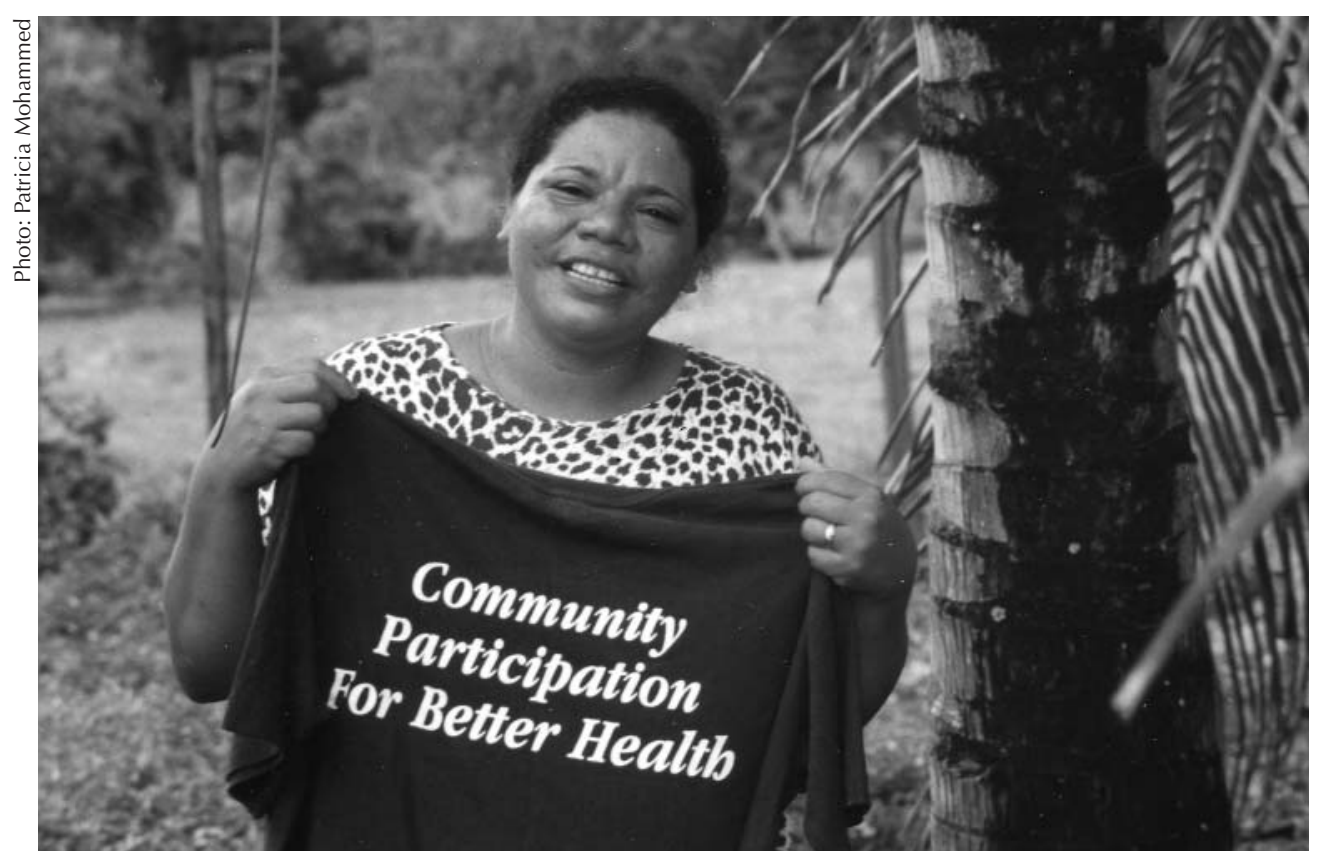




\section{Transforming Relationships in Pakistani Villages}

by Saumya Ramarao and Ali M. Mir

For several decades, the government of Pakistan has invested extensively in developing its capacity to provide reproductive health services. Nevertheless, relatively few women currently use such services within the public sector. Only a minority of women undergo antenatal checkups, and fewer than one in five give birth with the assistance of a trained attendant. In addition to its maternal health services, Pakistan launched a formal family planning program in the early 60s. Nearly 35 years later, however, less than one woman in three practices contraception (UNFPA 2003). Still fewer seek medical care for reproductive tract infections.

This low rate of use does not reflect women's stated reproductive desires: For example, for every woman who practices contraception, three more express a desire to control their childbearing but are not using the services of clinics or of community-based workers. Not surprisingly, Pakistan has a high birth rate as a result, as well as a high rate of clandestine abortion. Unsafe abortion accounts for one in every eight maternal deaths in Pakistan (Fikree 2002).

Pakistani women's access to reproductive health services is limited by several factors, most notably by social barriers. Many Pakistani women lack power within their marriages to make decisions about whether to practice contraception or to seek antenatal care. This fundamental restriction is strengthened by distance from services: More than two-thirds of women who do not use contraceptives live over two miles away from a known service source
(Sathar and Casterline 1998). A further impediment to care-seeking is women's perception that they will be treated poorly at the government clinics, where dismissive and rude providers are the norm. (See following section for a more detailed discussion of barriers to care.)

In the past, the government has carried out a variety of initiatives aimed at increasing contraceptive use. These include public information campaigns; demographically driven approaches to family planning, including targets and incentives; technical skills training for providers; improvements in logistics; and the introduction of new contraceptive methods. A key strategy has been the establishment of an extensive system of community health workers to provide basic health services, including family planning, at the village level.

Nonetheless-and Pakistan is not alone in this regard-such conventional interventions have made little more than a dent in contraceptive rates. Senior officials from the Ministry of Health and Population Welfare realized that they had to consider new measures to prevent pregnancy-related deaths by providing women who do not want to become pregnant with the means to control their fertility.

Zeba Sathar, the Population Council Director for Pakistan, believed that innovative strategies were needed to facilitate women's ability to overcome the sociocultural barriers that prevent them from accessing care, avoiding unwanted pregnancy, and protecting their own general health. Together with her colleague Anrudh Jain, at the Population 
Council, Sathar worked with government officials to design an intervention unlike any that had been conducted in Pakistan. Instead of tinkering with supply systems, new technologies, or targetbased approaches, this initiative sought to change the manner in which providers interact with both their clients and coworkers. What made it even more unusual is that it addressed the central issue of social power in care-seeking, in care-giving, and, of course, in negotiating desired outcomes, such as use of reproductive health services. This story describes that intervention and its outcomes, emphasizing the transformation of service provision that resulted at the community level.

\section{Why Services Were Failing}

According to Jain and Sathar, the series of barriers that constrain women's use of reproductive health services in Pakistan stretches from home to clinic and back. The entire continuum is characterized by women's lack of social power. First, both men and women have been socialized to place a low value on women's health needs. Additionally, in most marriages, the woman typically must defer to her husband and/or mother-in-law regarding decisions about her own health care, including whether to practice contraception. (For example, among women who want to postpone or terminate childbearing in Punjab, Pakistan, 40 percent cited their husbands' fertility preferences and/or perceived opposition to family planning as the obstacle to their practicing contraception.) Moreover, social customs and limited access to cash for transportation often prohibit her physical mobility outside the household.

Power differentials also characterize the care provided by clinic and com- munity-based workers. Typically, providers are condescending and abrupt with clients; visibly poor clients receive the worst treatment. Providers often interrupt and make treatment suggestions based on little or no real communication with the client. Moreover, the recommendations may be inappropriate to the woman's situation. In short, the clients perceive many providers as rude and incompetent, while providers

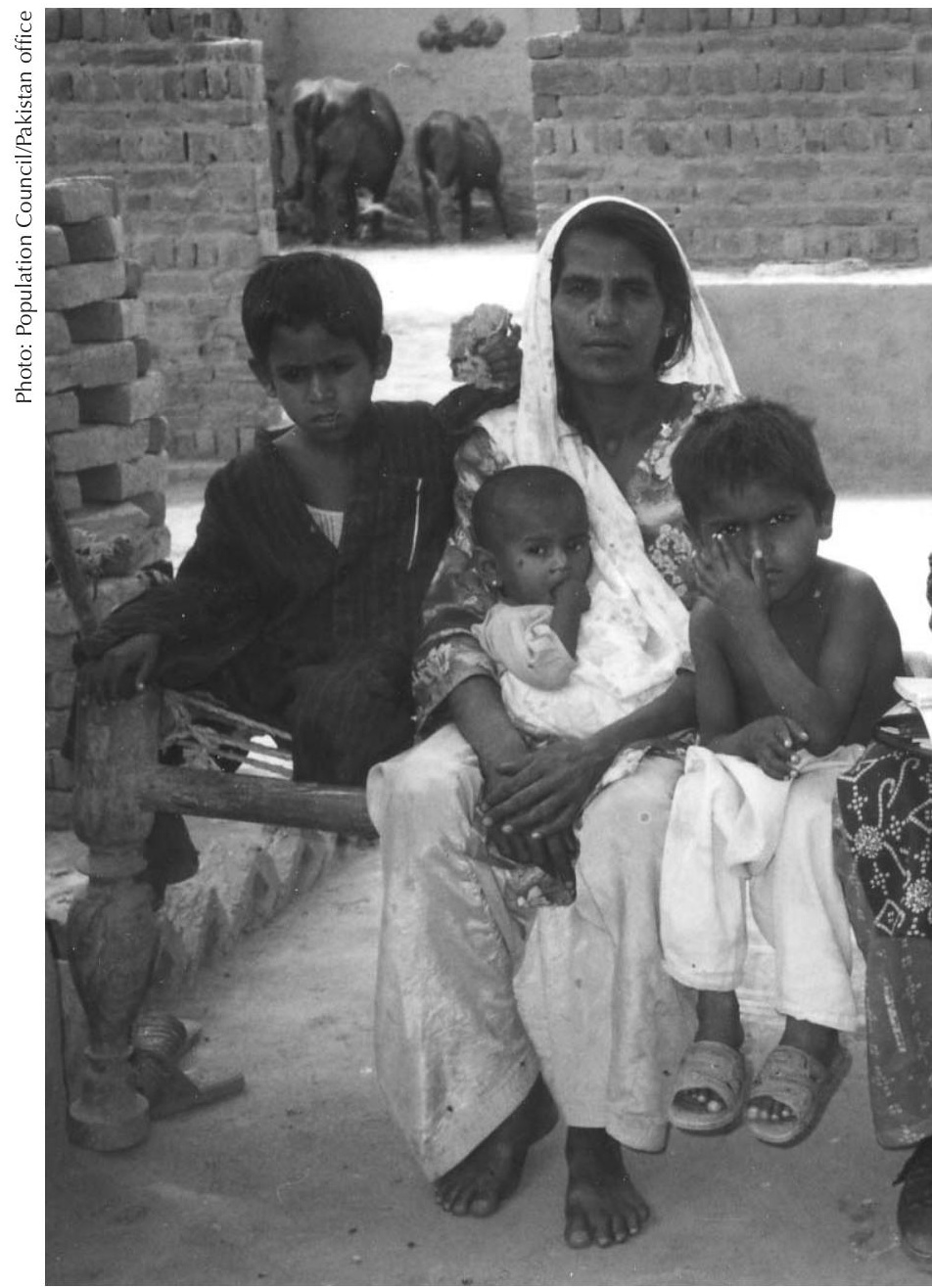

Both men and women have been socialized to place a low value on women's health needs. Social customs and limited access to cash for transportation often prohibit women's physical mobility outside the household. Partly as a result of these constraints, a minority of women receive antenatal care, and less than one in five gives birth with the assistance of a trained attendant. 
may view clients as an unpleasant nuisance. ${ }^{1}$ The only thing about which they seem to agree is that the provider holds the power to shape the interaction.

Sathar and Jain argued that women were not likely to use health services without addressing the two central obstacles in their way-social constraints and poor treatment by providers. They met with senior officials from the Ministry of Health and Population Welfare-Dr. Naushaba Chaudhury, then Director General at the Ministry of Population Welfare, and Dr. Reza Zaidi, Deputy Coordinator of the National

Power dynamics among staff-

shaped by education, class, and gender-were part of the problem.

Program for Family Planning and Primary Health Care-about tackling these obstacles directly. Fortunately, the concurrent reorganization of the Ministries of Health and Population Welfare created an openness to trying new approaches, and the government agreed to collaborate with the Council on an ambitious training program. As Sathar explained, "We wanted to address psychological, social, and physical access. We had to concern ourselves with enhancing women's power in the family, for example, seeking the support of family members, so they could seek care in the first place. We also had to transform the client-provider relationship, which included challenging providers' power over clients."

Jain and Sathar understood that power dynamics also characterized the rela- tionships between providers at different levels within the hierarchy. Senior staff typically speak in a rude and authoritarian manner to their supervisees. Anecdotal reports indicated a problem with sexual harassment in some sites. Moreover, lower-paid staff are generally excluded from any role in decisionmaking. As Sathar explains, "Our premise was that workers who feel powerless treat their clients poorly in turn; hence, there was a need to foster critical thinking among the staff about the entrenched social dynamics in their hierarchal relationships with each other."

Sathar stresses that it was necessary even to consider how power dynamics affected the personal lives of staff members outside of work. After all, female staff members go home every day to domestic situations in which their actions are typically circumscribed by their relationships to their husbands and/or extended families. Sathar recalls, "We were focusing on social power in a range of contexts."

In this way, the government embarked on a behavioral change training program for providers that went beyond typical counseling skills to include a focus on recognizing power dynamics in a range of human relationships. The objective was for trained providers to develop greater awareness about their interactions with other human beings; the desired outcome was for them to offer their clients greater respect and more useful support for meeting their reproductive health needs. Although providers at all levels were trained, the community-based workers who make home visits constituted the majority of trainees.

\footnotetext{
${ }^{1}$ In clinic settings, anecdotal evidence abounds about the particularly harsh treatment of poor or "scruffy" clients; for example, many clinicians conduct a superficial examination of a woman whose clothes are not clean. When the doctor is not present, paramedical staff often emulate this behavior, treating clients with the same disdain that characterizes typical doctor-client interactions.
} 


\section{Establishing Consensus on the Team}

The government asked the Population Council to design and test the intervention with public-sector workers in Punjab province. Jain helped shape a hypothesis, plan of action, and evaluation elements to ensure that the intervention was practical and could produce useful research findings. ${ }^{2}$ Sathar put together a team comprised of five Council staff, four of whom were physicians originally from either the public sector or from nongovernmental organizations (NGOs).

Initially, the medically oriented intervention team expressed hesitations about focusing on the client-provider relationship; instead, they leaned toward a technical course aimed at upgrading providers' technical skills. In the hopes of resolving this conflict and building consensus, Sathar organized role-play exercises in which she, Jain, and the team members enacted a series of typical public-sector encounters. They based their vignettes on their own experiences of observing workers or as patients.

For one such exercise, the two junior members of the team enacted a recent actual encounter one of them had experienced with a doctor. The "patient" expressed concern about a skin blemish. The "doctor" glanced at her blemish and wrote a prescription for a face cream without looking back at the client or offering instructions about how to use the cream. The patient, an educated professional in the health field, left without understanding what the rash was or how to treat itand felt frustrated. This simple example from their colleague's own experience enabled the physicians to see that such interactions are neither uncommon nor acceptable and may bear no relationship to the provider's technical competence.
The team developed a list of the behaviors exhibited during the visit of an ordinary female client. They observed that staff spend very little time with the woman; make no effort to learn what her problem is; speak to her in a judgmental tone; blame her for her situation; do not inquire about her home situation to assess what will work best for her; do not listen; do not provide her with choices; do not check to make sure that she understands instructions; and say nothing supportive to her.

In reflecting upon the interaction, the team had to acknowledge that doctors are far more likely to display negative behaviors than are lower-paid providers such as village workers, who are closer

The government embarked on an

behavioral change training program

for providers that went beyond

typical counseling skills to include a

focus on recognizing power dynamics

in a range of human relationships.

in social class to their clients and who reside in the same communities where their clients live. The doctors on the team also recognized that they had never been taught how to interact appropriately with patients.

The intervention team learned that the client-provider interaction is, in essence, an unacknowledged power relationship and reached a consensus that training should focus on improving these interactions by teaching interpersonal awareness communication skills, paying special attention to power in

\footnotetext{
${ }^{2}$ The project in Pakistan is one of four country studies that the Population Council is undertaking to document the feasibility of improving quality of care and the effect of improved quality on women's reproductive behavior. This effort is directed by Anrudh Jain.
} 
relationships. The training would reach all levels of staff, from supervisors and physicians to lady home visitors.

Because the village-based workers were both greatest in number and the most open to the ideas presented in the training, this effort became a communitylevel activity. Hence, this article focuses primarily on those workers and how they were transformed by this intervention.

\section{Laying a Foundation for the Training}

After reviewing a range of training resources, the team tailored a workshop specific to its goals and to the cultural setting. The Population Council turned to Rozan, a local NGO that had conducted training for health professionals and police officers on how to interact with the public. Public health employees, like police offers, are considered to be more powerful than the public they serve and are often perceived in a negative light.

Ambreen Ahmed, a psychologist at Rozan, and her colleagues taught their behavior-change model to the Council's intervention team (see box below). Going into the Rozan workshop, most of the Council team was highly skeptical about the usefulness of "consciousness raising about interpersonal power" as a stimulus for the kind of the changes they hoped to promote among public servants. At the end of the five-day workshop, however, they were convinced that the Rozan behavior-change training was effective. They set about adapting the exercises for reproductive health providers.

\section{Rozan: Enhancing Awareness of Self and Others}

Rozan's behavior-change training seeks to strengthen specific interpersonal skills:

- Becoming more aware of how others respond to our behavior. As we pay more attention to the responses elicited by our behavior, we become more sensitive to our own strengths and weaknesses, and tend more to behave in ways that elicit a positive response.

- Becoming more aware of how inequality, including gender inequality, operates in relationships. By reflecting on concrete situations, trainees learn about gender and power dynamics, about how these translate into poor health outcomes for women, and they learn ways to break hierarchies and promote egalitarianism.

- Reflecting on one's role in society. Public behavior that elicits a positive response reinforces a sense of one's role and responsibilities in society. In one exercise, participants imagine an ideal society. Typically, participants identify a society that provides universal justice, food, shelter, security, health care, and livelihood. The next part of the exercise asks participants to identify their role in that society and how they can help to create such a world.

- Improving interpersonal communication skills. Trainees learn how we transmit messages about how we see ourselves vis-à-vis others. As an example, Rozan trainers tell a story of three men breaking stones on the side of a road. On being asked what they were doing, the first man said that he was breaking stones; the second that he was breaking stones to build a road; the third, that he was breaking stones so that a road could be built for the children going to school. Thus, each man's message incorporated a different perspective about his relationship to others. 
The team's next step was to identify specific, teachable behaviors to help providers to: (1) "humanize" their relationships; (2) assess the social contextincluding dynamics of power and gender-in which a client lives that governs her ability to seek care; (3) help a client define her own sexual and reproductive choices; and (4) in some measure empower her to implement her decision.

The team wanted a model that would guide staff in executing these behaviors and that went beyond existing communication models for improving clientprovider interactions. The model they developed-practical for use in any kind of health service-is called SAHR. SAHR means "dawn" in Urdu, suggesting a new beginning for providers. More importantly, SAHR is an acronym for a list of sequential behaviors:

- Salutation refers to overall rapport building: greeting the client, inquiring about her well-being, about her family members, how she traveled to the clinic, and other culturally appropriate questions to generate warmth and build the confidence necessary for any authentic interaction. The word "salutation" also implies respect, for example, by sitting at the same level with the client, whether on a chair or (in the community) on the ground.

- Assess implies going beyond simply asking about the client's immediate medical needs to seeking understanding of the issue in a wider dimension. For example, community workers should observe the nature of relationships between various family members, so that they can identify potential gatekeepers or allies whose support will be important in allowing the client to adopt the plan she wants. This approach acknowledges existing power relationships within the family, but at the same time, empowers women to capitalize on these relationships in ways that allow them to meet their health needs in the short run.

- Help the client by providing relevant information, choices, and support for making and implementing her own

\section{The SAHR model emphasizes}

dynamics of social power and assists providers in helping clients

meet their needs. The commanding

principle is respect for the equality

of human beings and an awareness

of the ways in which equality is

constantly being undermined.

decision. Most providers need to learn how to assist the client to sort through information and enable her decisionmaking. Information that the providers supply can help to empower clients when they try to convince uncooperative family members about the choices they would like to make.

- Reassure by informing the client that a decision or solution can be renegotiated if the current option does not work; the provider can give referrals, suggest a return visit, and offer supportive messages (for example, she or he will talk to family members who may present obstacles).

Simply put, SAHR is a model that emphasizes dynamics of social power and assists providers in helping clients sequentially to meet their needs. The commanding principle is respect for the equality of human beings and an awareness of the ways in which equality is constantly being undermined. 
example, tricking the person with an offer to shake hands or softening them with flattery. This exercise demonstrated the various ways that people seek to alter the balance of power in a situation.

\section{Addressing Power \\ Dynamics in Client- Provider Relationships}

The training included a generic communication-skills module that strengthened providers' listening and verbal and nonverbal communication skills and their ability to deal with difficult clients. Video vignettes (made by the training team) showing negative interactions enabled providers to see how harsh their behavior looked and felt from the outside; positive vignettes specifically modeled constructive behaviors.

To underscore the importance of assessing a client's situation thoughtfully, the trainers conducted an exercise in which they asked the participants if they knew what their wristwatches look like. The trainer asked them each to draw the dial without looking at it. Comparing the drawings to the watches, which they see every day and which are far less complex than a human being, reminded the participants how easy it is jump to faulty conclusions about the situation of another person. This exercise led to a discussion about the need to bring humility rather than a sense of omniscience to their observations of and interactions with clients.

\section{Challenging Existing Hierarchies Among Staff}

Although the training emphasized the ways in which power relations general- ly govern the lives of clients, it also illustrated the point that the same rules govern most providers' lives as well. The training team promoted this awareness in several ways. For example, they decided to break with tradition by inviting staff at all levels to participate jointly-from male doctors to lady home visitors. They included community workers from both the population welfare department and the health department in the same workshop, to help erase the sense of inequality that members of these groups feel. ${ }^{3}$

When the participants arrived on the first day of the training, they found not only an unexpected diversity among their fellow trainees, but learned that everyone (including the trainers) was sitting on the floor. The trainers reinforced their messages about equality with role-play exercises involving paramedics acting as doctors and doctors as clients. The providers clearly noted and worked with these disruptions in their everyday patterns of status and gender that characterized their institutional relationships.

In an explicit attempt to enable participants to enhance their own selfawareness, the trainers conducted an exercise focused on identifying their strengths and weaknesses. One by one, each participant told about some personal experience and the feelings it had engendered. This sharing fostered a sense of trust among participants. Finally, the trainers adapted Rozan exercises that enabled participants to reflect on their role as public servants in Pakistani society. The workshop ended with a discussion acknowledging that each individual—regardless of her or his

\footnotetext{
${ }^{3}$ Even though staff from both the health and the population welfare departments serve the same clients and provide similar services, they regard themselves as separate. The recent merger of the two ministries had revealed an underlying rivalry between them; community workers of the health department tend to look down upon the community workers in the population welfare department because their training programs have been weaker.
} 
official role-contributes to the environment and that nobody acts in isolation.

At the conclusion of the training, participants were asked for anonymous feedback. They indicated that they appreciated having an opportunity to discuss abstract concepts such as gender and power in a concrete way. They also enjoyed the interactive format and the feeling of community generated during the workshop, both of which were a departure from their usual training experiences.

One physician, who was also a district manager, responded to the training with the following comment: "After participating in the role-plays where I had to take my sick child to a provider, for the first time I felt how humiliated, helpless, and frustrated you can feel if the provider is hostile and arrogant toward you. It was indeed a very bitter experience. The importance of how you behave with your client dawned on me for the first time. I can now empathize with the poor clients. I [will] make it part of my supervisory visits to see to it that clients are dealt with in a humane manner by the providers as envisaged in the SAHR approach."

The workshop had its difficult aspects, most of which had to do with making abstract concepts understandable. For example, the trainers realized that they had underestimated how strange the concept of "client-centered services" would appear to public-sector providers in Pakistan. Although the trainers attempted to explain in detail both the concept and the specific objectives of the workshop, participants had no point of reference for these ideas. Hence, they had no clear sense of what benefits the training might produce for them; this confusion generated a skepticism that took several days to lessen. The trainers realized that future workshops should begin from within the participants' own frame of reference.
Similarly, three days elapsed before participants began to sense the link between self-awareness and their role in society. Because the trainers had had the same experience during the Rozan training, they were prepared for this delayed response. Nonetheless, they felt some tension while waiting for the participants to absorb this message. This training may require a more intuitive model.

Not everyone responded equally well to the workshop. Because the workshop modeled equality, the lower-level stafffor whom it became an exercise in empowerment-responded more favorably than the doctors, who initially were skeptical. Moreover, because the community workers were younger and newer at their jobs, they may have been more receptive than the doctors to new ideas. Despite the physicians' skepticism, the team felt their presence was essential, because the mixing of staff in an equalizing environment was what allowed all participants to experience and reflect on the issue of social power.

\section{The Initial \\ Assessment}

One premise of the workshop was that trained providers would feel empowered to address inequalities in their work and home environments. Indeed, the workshop illuminated some of the discomfort people had been tolerating. One community-based worker chose to disclose instances of sexual harassment she had endured from her supervisor. Another woman felt emboldened enough to leave an abusive marriage and set up an independent household, a courageous step within the social and cultural context of Pakistan.

To learn whether the training experience led to changed interactions with clients, the trainers observed a subgroup of the community-based providers two 
months after the workshop and recorded their specific behaviors. ${ }^{4}$ The results were mixed.

The community workers had clearly changed the way they conducted their house visits. Instead of honing in directly on the "eligible woman" as they had done previously, they focused more broadly on the family and on community health. They exchanged greetings with various family members such as mothers-in-law, inquiring after their health and offering suggestions. As a result, many mothersin-law-who are not the targeted beneficiaries of any government program but who wield enormous influence over young wives-also received attention and warmed to the visitor. As a result, the community worker's visit no longer caused family friction hurtful to the client.

The community workers were not fully applying the SAHR model, however. They were not building upon the rapport they established to assess the specific needs of clients. For example, in discussing family planning, providers rarely asked a woman whether she wanted to prevent pregnancy for a few years or permanently, or whether she had any previous experience with contraception. They were still more likely to choose a method for the client and advise her about using it.

Rather than give up on these workers or decide that the SAHR model was too ambitious, the team decided to invest in further training. Four months after the initial training, all the participants were given an additional two-day workshop emphasizing topics that needed reinforcement.

\section{The Assessment of Impact}

After the second training, the team again observed interactions between providers and clients both in the pilot area and in a control area where providers did not undergo training. ${ }^{5}$ They also conducted focus-group discussions with both groups. The findings from these sources corroborated each other.

\section{Client Feedback}

Among the clients, some stated that the community health workers had always treated them satisfactorily. Hence, because no pretraining focus-group discussions were conducted, assessing how much positive behavior is a direct result of the training is difficult. Those women who reported a change in the worker's behavior made comments like the following:

Now she questions more and sits for a longer time and discusses.

She talks with my mother-in-law and convinces her to give me permission so that I can practice family planning.

Some women expressed a desire that community workers be able to treat more problems:

They (the workers) should have medicines for white discharge. . . Sometimes the problem is so serious that we have to go far away to a town or the woman may die.

\footnotetext{
${ }^{4}$ Although clinic staff are not the focus of this report, their behavior was also followed; they were found to be applying the lessons of the training less effectively than the community workers were.

${ }^{5}$ Again, results were most satisfactory among community workers. The observers assessed whether these workers inquired about the family's well-being ( 50 percent of trained workers did so compared with 34 percent of workers observed in the control areas); about who makes major decisions in the household (69 percent versus 55 percent, respectively); about whether the client can persuade that person (27 percent versus 14 percent, respectively); and about whether the client must seek permission to go for an examination (76 percent versus 16 percent, respectively). Providers who underwent training were also more likely to explain more than one contraceptive option, to encourage clients to speak, and to verify whether they had understood instructions pertaining to their choice of method.
} 
The workers described using their new skills to assess a client's overall needs in a manner that was sensitive to her background.

I assess the situation of the home, whether the client is worried or happy. If she is worried, then I ask the reason for her worries.

We have come to know about immunization and reproductive health ... about where to refer the client if a child or elder becomes sick. I also have come to know who has power in the house and talk with her first so that she does not get angry.

For those women who cannot talk with their husbands and are afraid, we try to help them and try to create a feeling of self-awareness.

Perhaps more importantly, providers are behaving in a less authoritarian manner and beginning to include the client as an equal partner. This shift is seen clearly in the way family planning services are being delivered.

Previously we used to say, have yourself operated on, but now we tell them to make their own decisions.

We have to ensure that there is a level of equality, keep eye-to eye contact while talking, listen to her attentively, use reflective listening, behave properly.

I used to assume that people should come to me instead of my having to visit them. After the training, I visited three or four households that earlier I would not visit.

The providers sense the effect of their efforts:

Now clients also discuss their personal matters with us.

Now they think us as their well-wishers. Previously, our behavior was aggressive. They did not tell us their family problems, but now our behavior has changed.
Now people have confidence in me, and I also have confidence in them.

The workers also report some persistent challenges:

If the power of decision is with the husband or father-in-law, then the daughter-in-law says that she cannot go with us without his permission. Such a situation is difficult.

Our family members say that there are some people whose position or reputation is not good; they do not allow us to go there.

Women are afraid to deliver in hospital. It is also a problem that there is no lady doctor in the hospital. We explain that there can be a problem during delivery. We tell them that the treatment is free, but it is difficult to convince them.

They don't tell us the date of their menses. If they are pregnant, they don't even tell us that. Our register gets spoiled because the clients do not tell us. Sometimes they tell us false dates of delivery. They say, "The government does not feed our children. Why do you come and note their names?"

\section{Workers' Relationships with Supervisors}

Some workers report that some supervisors are now more supportive and are offering more guidance:

She used to tell us how to work, but now she explains in depth, [for example], how to fill the community chart. ... If we did anything wrong, she used to get angry, but now even if we ask repeatedly, she does not get angry.

She used to be very strict and snubbed us, but now the supervisor explains things with patience, and if there is any problem, she tries to solve it. 
Previously, we were afraid that our supervisor was coming; she used to go and complain in the office and have our salary stopped.

This improvement in worker-supervisor relations is not, however, universal:

Supervisors' training should be conducted again so that [our supervisor] does not snub us in front of others.

She is same as before. What she did before, she is still doing. There is no change in her behavior and method of supervision.

\section{Improved Institutional Operations}

Another outcome of the workshop was that the staff of the health and the population welfare departments drew closer to each other. The workshop was their first shared experience, and they are beginning to provide referrals to each other's services. In this way, the workshop contributed to consolidating the national merger between the Ministry of Population Welfare and the Ministry of Health.

\section{Expansion and Replication}

In 2001, the Pakistani government expressed interest in replicating the SAHR model on a larger scale. Dr. Zaidi, from the National Programme for Family Planning and Primary Health Care, together with a representative from the United Nations Population Fund (UNFPA), conducted an independent monitoring of sites where staff had undergone the training. Zeba Sathar admits that she was initially concerned about this visit:

I didn't know whether they would appreciate the intervention being tested, especially since both gentlemen were physicians, and our train-

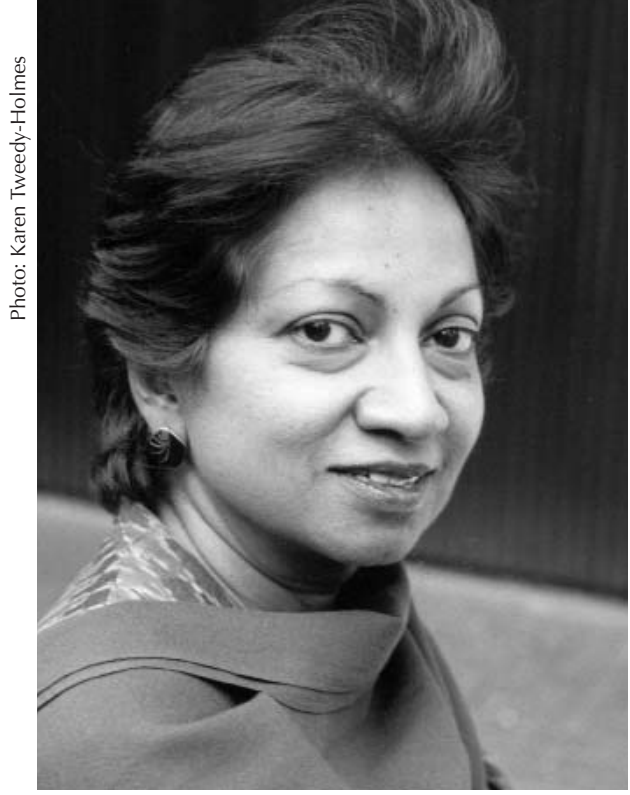

According to Zeba Sathar (above), "We have unraveled one of the difficulties toward empowering poor, uneducated women to meet their reproductive health needs, but there is still a long way to go in this process of transforming long-entrenched attitudes and behaviors."

ing did not focus on improving providers' technical competence.

Sathar need not have worried. Dr. Zaidi returned from his visit convinced that the SAHR training had had a positive impact on his cadre of lady health workers. He had spoken with a number of the workers, who impressed him with their confidence and engagement.

Based on the government's enthusiasm, UNFPA/Pakistan signed an agreement with the Population Council in 2002 to train 3,000 additional community and clinic workers in five districts, along with a parallel training for Dr. Zaidi and a number of federal and provincial program managers. To carry out the expansion, the Population Council team is reproducing the training materials and conducting a training-of-trainers. Efforts are also under way to apply the SAHR model to obstetric-care providers, communitybased transportation workers (responsible for transporting women to healthcare facilities during emergencies), and medical students. 


\section{Remaining Challenges}

The project faces a series of ongoing challenges. For example, UNFPA's support for expansion raises questions of maintaining the quality of the intervention. The expansion-phase workshops will be led by Ministry of Health employees, who may not be as keenly motivated as was the original Population Council team. Moreover, the government does not currently have a plan for assessing and responding to the need for periodic follow-up training. Council staff are hoping that adequate monitoring of the expansion will enable the government to identify areas that require modification or attention.

Building demand from clients is another challenge. Zeba Sathar believes that the team should have conducted parallel, modified workshops for women at the village level. Such workshops could raise women's expectations regarding their rights within the family and what they receive from health-care providers, and provide them with support and tools to begin exercising those rights. The Council hopes to organize such community-based workshops in the future. As Sathar says, "We have unraveled one of the difficulties toward empowering poor, uneducated women to meet their reproductive health needs, but there is still a long way to go in this process of transforming long-entrenched attitudes and behaviors."

Chronic systemic problems-similar to those in most developing country settings-ultimately undermine quality of care and demoralize workers. These problems include delayed salary payments, disruption in supplies of medicines, and lack of vehicles for transporting clients or supervisors. Clients' continuing negative experiences at clinics eat away at the goodwill created by the community worker who gave them the clinic referrals.

In training they had given us a list. We have not received oral rehydration supplements for the last year. We are not getting alcohol, bandages, cotton, or chloroquine.

This month I took three clients for tubal ligation. On our return, the vehicle did not even leave us at the bus stop because the driver said that he didn't have time. Patients at that stage are only semiconscious, and they keep staggering.

Persistent culturally entrenched condescension toward lady home visitors remains:

The doctors don't give any importance to us. Yesterday, the watchman and the attendant did not allow us to go inside to meet the doctor, and the doctor went away.

The attendants don't give importance to ladies at all, and it is worse with lady health workers. Even though we have brought the patient and even if she is in serious condition, no priority is given. They see us according to our turn. Clients who go with us they say, "You are attached with hospital but still they don't listen to you." We feel insulted in front of them.

Perhaps more important, the Pakistani government continues to evaluate workers on the basis of targets achieved. Such an emphasis ultimately constrains the workers' ability to put the needs of the client foremost. As Jain explains, "Method-specific targets and quality of care are incompatible. Targets force providers to motivate or persuade women to accept a specific method in order to fulfill their targets. On the other hand, quality is about helping a woman choose a method appropriate to her needs." 


\section{What Does It Add Up To?}

The intervention team knows that a training program alone cannot fundamentally transform deeply entrenched cultural and institutional conditions with one or two workshops. Nonetheless, this intervention has effected a small but meaningful shift in the way health workers interact with clients, in their own self-awareness, and in their job satisfaction. By focusing on relatively simple behavioral changes anchored to a fairly sophisticated analysis of power dynamics, the SAHR training can make a large difference for a few people, and a moderate but real difference for millions. As Anrudh Jain, the original force behind this project, says, "This is do-able. And it's getting done."

\section{Lessons Learned}

Even a large, bureaucratic, and authoritarian public-sector program can improve community-based services by focusing not on technology, targets, or infrastructure but, rather, on power and gender issues.

When providers learn to treat a client as an equal and active partner who is an "expert" in her own right, the provider-and not just the client—ends up better satisfied.

Those who are lower in the hierarchy_-such as community workers - are more willing to change and modify their behavior. Providers who are higher in the hierarchy, including physicians and supervisors, may need regular reinforcement to internalize new ideas about power and gender so that they become more sensitive and sympathetic toward their clients.

\section{References}

Fikree, Fariyal. 2002. "Reproductive health in Pakistan: Evidence and future directions." Journal of Pakistan Medical Association 52(1): 34-41.

Sathar, Zeba and John Casterline. 1998. "The onset of fertility transition in Pakistan." Population and Development Review 24(4): 773-796.

Sathar, Zeba, Minhaj ul-Haque, and John B. Casterline. 1998. "Unmet need in Pakistan: Findings from a study in Punjab." Paper presented at international workshop on "Unmet Need for Family Planning in Comparative Perspective." Nairobi, Kenya, 23-24 June.
Workshop organized by the Population Council.

United Nations Population Fund (UNFPA). Country programme document for Pakistan. 31 October 2003. <http://www.unfpa.org/ exbrd/2004/firstsession/dpfpa-cpd-pak7.doc.p.2>. Accessed 20 March 2004.

\section{A cknowledgments}

We wish to thank Debbie Rogow for her substantive contributions and editorial guidance as we prepared this article.

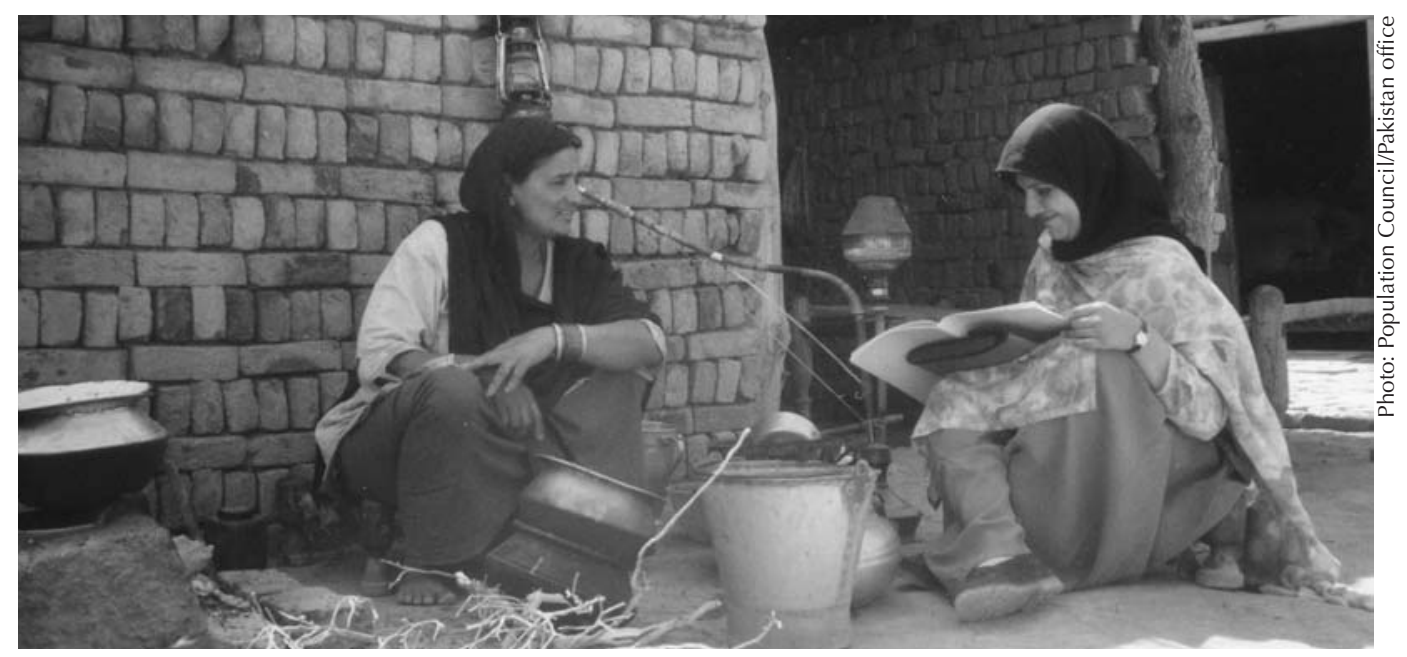


The Programme of Action of the 1994 International Conference on Population and Development held in Cairo calls on governments not only to ". . . promote much greater community participation in reproductive health-care services," (UN 1995, Paragraph 7.9) but also to work toward ". . . advancing gender equality and equity and the empowerment of women . . . [as] cornerstones of population- and development-related programmes" (UN 1995, Principle 4).

The interventions by the Belize Family Life Association and the Pakistani government were designed with an eye toward tracking results, and both projects have produced abundant, nuanced documentation indicating that individuals are absorbing new values about gender as it applies to themselves and the world around them. Nevertheless, the assessment of community-based efforts to change gender relations is still in its infancy.

Programs and researchers assessing project effects are seeking to measure changes in meaningful indicators of gender equity at the levels of the individual, couple, family, community, and society. They face a constellation of challenges in this task. First, relevant outcome indicators-such as communication and decision-making about sexuality, ease of movement, freedom from violence, control over resources, and public leadership-are typically shaped by more than one effort, policy, or cultural trend. Programs that wish to posit about causality need a new generation of methods that make their contribution visible. Moreover, many of the most potent and lasting outcomes may take years to become manifest in a quantifiable way.

Following are some examples of community-based, gender-sensitive empowerment programs that are currently undertaking new approaches to evaluation:

- Girls' Power Initiative, an education and social-support project in Nigeria, has designed a participatory evaluation focusing on behavioral markers of newly acquired assertiveness, for example, "I can express myself in public," and "I can now mention any part of the body, like the vulva."
- In India, the First Time Parents Project is fostering social cohesiveness and gender sensitization (along with providing information and services); the program aims to increase the ability of married girls to communicate with their husbands and to act on their own behalf in a range of areas, including sexual and reproductive health.

- Project $\mathrm{H}$, a collaborative evaluation of community-based programs promoting gender-equitable attitudes among young men in Latin America, is measuring how attitude shifts correlate with changes in condom use and violent behavior.

- The Ishraq project promotes literacy, life skills, and recreational activities among girls in rural Egypt. Progress toward the long-term goal of changing norms regarding girls' roles is being assessed by measurable shifts in such outcomes as their mobility and time use, their knowledge of key health and rights issues, their functional literacy, and their social connectedness.

Traditional population programs have invested over decades in the development of outcome indicators that reflect progress toward their goals. Similar investments are needed-in long-term experimental interventions and in a range of evaluation approaches - to ensure that community-based empowerment programs can generate lessons that help us meet the mandate of Cairo.

\section{Reference}

United Nations. 1995. "Programme of Action of the International Conference on Population and Development, Cairo, Egypt, 5-13 September 1994." UNDoc.A/CONF:171/ 13/Rev.1. New York: UN. 
En la actualidad muchos programas reconocen que los trabajadores comunitarios juegan un papel complicado y trascendente como agentes del cambio social. Esta edición de Quality/Calidad/ Qualité comparte la experiencia de dos programas tradicionales de planificación familiar basados en clínicas que encontraron nuevas maneras de trabajar en sus comunidades.

En varios sentidos estos dos programas, y las iniciativas que llevaron a cabo, no podrían ser más diferentes. La Belice Family Life Association (BFLA) es una ONG de tamaño mediano en un pequeño país caribeño. La BFLA prácticamente no tenía experiencia en el trabajo comunitario cuando su gerencia decidió organizar grupos de discusión sobre temas como violencia, enfermedades de transmisión sexual, y el embarazo entre adolescentes. Además de ayudar a que hombres y mujeres se "escuchen" entre sí, el personal del proyecto aprendió a trabajar con dueños de prostíbulos, administradores de escuelas y funcionarios políticos gracias a esta iniciativa. Los diálogos públicos han conducido a cambios en la comunicación de muchas parejas en cuanto a su propia relación, y a un aumento en las visitas por planificación familiar a la clínica. Además, han transformado la misión de la BFLA y el perfil de la organización — tanto en las comunidades locales como al nivel nacional.

El segundo caso tiene que ver con el gobierno de Pakistán, el cual maneja un enorme programa de planificación familiar con metas concretas y una red de trabajadoras comunitarias al nivel de aldea. El programa y la red funcionan desde hace mucho tiempo y están profundamente arraigados. El gobierno trabajó con el Population Council para proveer capacitación en comunicación con un enfoque en la problemática del poder social en el hogar, la sociedad y en los sistemas de provisión de servicios. La capacitación hizo que las trabajadoras comunitarias estuvieran al mismo nivel que doctores de mucha trayectoria en el momento de cuestionar el poder social. Los trabajadores comunitarios comenzaron a interpretar su trabajo, y sus vidas en general, dentro de un contexto social más amplio, y también empezaron a relacionarse más respetuosamente con sus propias clientes. Hoy dicha capacitación se está implementando en otras regiones y está ayudando a mejorar la calidad del intercambio que miles de trabajadoras comunitarias tienen con decenas de miles de clientes.

A pesar de las grandes diferencias entre una ONG en Belice y el gobierno de Pakistán, estas dos experiencias comparten algunos supuestos fundamentales: 1) el poder influye en las relaciones sociales; 2) la falta de poder de las mujeres es un obstáculo importante en cuanto a su capacidad de proteger su propia salud sexual o reproductiva; 3) las trabajadoras comunitarias pueden ayudar a que las mujeres amplíen su "zona de influencia", tanto en el hogar como en el sistema de provisión de servicios; y, 4) la capacitación para trabajar al nivel comunitario debe incluir el personal en todos los niveles, incluso la alta gerencia y los formuladores de políticas. 
Nombreux sont les programmes qui reconnaissent maintenant le rôle complexe et puissant que les animateurs sociaux peuvent jouer comme agents de changement social d'ensemble. Cette édition de Quality/Calidad/Qualité présente les expériences de deux programmes de planification familiale opérant, comme le veut le modèle traditionnel, à partir d'une clinique, qui se sont efforcés de travailler dans la communauté d'une manière différente.

A bien des égards, les deux programmes mis en exergue - et les initiatives menées par leurs responsables sont complètement différents. L'association bélizienne pour la vie familiale (BFLA, Belize Family Life Association) est une ONG de taille moyenne opérant dans un petit pays des Caraïbes. La BFLA n'avait presque pas d'expérience antérieure dans le domaine du travail communautaire quand ses responsables ont décidé d'organiser des groupes de discussion publique sur des sujets tels que la violence, les maladies sexuellement transmissibles et la grossesse chez les adolescentes. Le personnel du projet a non seulement aidé les hommes et les femmes à se prêter une écoute mutuelle, il a aussi appris à travailler avec les propriétaires de maisons de prostitution, les administrateurs scolaires et les élus. Les débats publics ont suscité un changement dans la manière dont de nombreux couples communiquent au sujet de leur relation ; ils ont entraîné l'augmentation du nombre de consultations de planification familiale, et transformé la mission ainsi que le profil de la BFLA à la fois dans les collectivités locales et à l'échelon national.

La deuxième étude de cas relate l'expérience du gouvernement pakistanais qui gère un programme national de planification familiale de taille énorme mais solidement établi et étroitement ciblé, basé sur un système de travailleurs ruraux existant de longue date. Le gouvernement a collaboré avec le Population Council pour fournir une formation en communication qui mettait l'accent sur la façon dont le pouvoir social s'exerce au sein du foyer, dans la société ainsi que dans les systèmes de prestation de services. Au cours de la formation, travailleurs ruraux et médecinschefs se sont vus placés sur un pied d'égalité dans le cadre de la remise en question du pouvoir social. Les travailleurs ruraux ont commencé à considérer leur travail, ainsi que leur propre vie, dans un contexte social plus large, et à faire preuve de plus de respect envers leurs propres clients. L'intervention, en cours d'élargissement à d'autres régions, a amélioré la qualité des interactions que des milliers de travailleurs ont avec des dizaines de milliers de clients.

Malgré les différences profondes qui existent entre I'ONG bélizienne et le gouvernement pakistanais, les deux études de cas ont en commun les idées essentielles suivantes : 1) Les relations sociales sont basées sur une relation de pouvoir ; 2) le manque de pouvoir social des femmes les empêche de veiller à leur propre santé sexuelle et reproductive ; 3) les travailleurs ruraux peuvent efficacement aider les femmes à élargir leur zone d'influence aussi bien à la maison qu'au niveau du système de prestation de services ; 4) la formation des animateurs sociaux doit être complétée par celle du personnel à tous les niveaux, y compris les cadres supérieurs et les décideurs. 


\section{About the Authors}

Susana Galdos is Principal Program Associate at Management Sciences for Health. As a longtime leader in the Peruvian NGO Movimiento Manuela Ramos, Galdos directed the ReproSalud project.

Lucella Campbell is a Senior Program Advisor at International Planned Parenthood Federation/Western Hemisphere Region.

Patricia Mohammed is a Senior Lecturer at Centre for Gender and Development Studies, University of West Indies, St. Augustine, Trinidad and Tobago.

Debbie Rogow is Editor of $Q / C / Q$.

Saumya Ramarao is a Program Associate at the Population Council in New York.

Ali Muhammad Mir is Director of Programs at the Population Council office in Pakistan.

Nicole Haberland is a Program Associate at the Population Council in New York.
Advisory Group

$\begin{array}{ll}\text { Delia Barcelona } & \text { Laura Laski } \\ \text { Gary Barker } & \text { Ann Leonard } \\ \text { Carmen Barroso } & \text { Ann McCauley } \\ \text { Judith Bruce } & \text { Liz McGrory } \\ \text { Batya Elul } & \text { Manisha Mehta } \\ \text { Susana Galdos } & \text { Suellen Miller } \\ \text { Kirrin Gill } & \text { Saumya Ramarao } \\ \text { Françoise Girard } & \text { Julie Reich } \\ \text { Nicole Haberland } & \text { Ann Starrs } \\ \text { Katherine Kurz } & \text { Cynthia Steele }\end{array}$

Production Staff

Editor: Debbie Rogow

\section{Research and editorial assistant:}

Michelle Skaer

Project editor: Karen Tweedy-Holmes

Designer: Mike Vosika

Translators: Paul Constance (Spanish) and Jeannette Ndong (French)

We invite your comments on Quality/Calidad/Qualité. If you would like to be included on our mailing list, please send an e-mail to: qcq@popcouncil.org. Most past editions are available online at $<w w w$.popcouncil.org/publications/qcq/default.htm $>$. The following are also available in print; single or multiple copies may be ordered by e-mail:

Celebrating Mother and Child on the Fortieth Day: The Sfax Tunisia Postpartum Program (English only), no. 1, 1989.

Man/Hombre/Homme: Meeting Male Reproductive Health Care Needs in Latin America (English, Spanish), no. 2, 1990.

The Bangladesh Women's Health Coalition (English only), no. 3, 1991.

By and For Women: Involving Women in the Development of Reproductive Health Care Materials (English, Spanish), no. 4, 1992.

Gente Joven/Young People: A Dialogue on Sexuality with Adolescents in Mexico (English, Spanish), no. 5, 1993.

The Coletivo: A Feminist Sexuality and Health Collective in Brazil (English, Portuguese, Spanish), no. 6, 1995.

Doing More with Less: The Marie Stopes Clinics of Sierra Leone (English only), no. 7, 1995.
Introducing Sexuality within Family Planning: Three Positive Experiences from Latin America and the Caribbean (English, Spanish), no. 8, 1997.

Using COPE to Improve Quality of Care: The Experience of the Family Planning Association of Kenya (English, Spanish), no. 9, 1998.

Alone You Are Nobody, Together We Float: The Manuela Ramos Movement (English, Spanish), no. 10, 2000.

From Patna to Paris: Providing Safe and Humane Abortion (English only), no. 11, 2001.

Universal Sexuality Education in Mongolia: Educating Today to Protect Tomorrow (English only), no. 12, 2002.

What about Us? Bringing Infertility into Reproductive Health Care (English only), no. 13, 2002.

"My Father Didn't Think This Way": Nigerian Boys Contemplate Gender Equality (English, French), no. 14, 2003. 
2uality/Calidad/Qualité/ 